\title{
Værdiformsanalytisk rekonstruktion af Kapitalen. Del 4
}

\section{Analysen af kapitalens cirkulations- og reproduktionsproces.}

\author{
Michael Eldred, Marnie Hanlon \\ Lucia Kleiber og Mike Roth.
}

\section{Introduktion.}

I denne del præsenteres en værdiformsanalytisk rekonstruktion af Kapitalens 2. bind, som er det mest oversete bind i den marxistiske tradition. Engels' forudsigelse, at »andet bind (vil) vække stor skuffelse, fordi det er så rent videnskabeligt og ikke indeholder meget agitationsmateriale « (Engels til Sorge, 3.6. 1885; B, 296) skulle vise sig at holde stik. Den foreliggende artikel indeholder heller ikke umiddelbart agitationsmateriale. Dette betyder dog ikke, at vi tilstræber et bidrag til en lærd diskussion med økonomiske professorer. Vi tilstræber at give - $ø \varnothing r$ vi sige det? - dialektisk indsigt i den størrelse, som kaldes kapitalistisk økonomi, og med denne indsigt - om ikke bevæge bevidstheden - så i det mindste rokke ved den gennem fremstillingen af totalitetens formbestemte modsigelser.

I begyndelsen af Kapitalens 3. bind skriver Marx:

»I deres virkelige bevægelse konfronteres kapitalerne i konkrete former af en sådan art, at kapitalens skikkelse i den umiddelbare produktionsproces og dens skikkelse i cirkulationsprocessen blot fremtræder som særegne momenter. De skikkelser, som kapitalen antager, som vi skal udvikle det i denne bog, nærmer sig altså skridt for skridt den form, hvori de selv optræder på samfundets overflade, $i$ de forskellige kapitalers vekselvirkning i konkurrencen og i produktionsagenternes sædvanlige bevidsthed «. (Rh 3, 36; K3, 33)

Den foreliggende rekonstruktion repræsenterer en bestemt fortolkning af denne passage. De kapitalskikkelser, som Marx refererer til, er handelskapital og bankkapital, som først udvikles af Marx i 3. bind efter cirkulationsanalysen. I modsætning hertil udvikler vi disse »skikkelser « - og giver begrundelse for vores omplacering - i den foreliggende artikel (§ 49f). Vores fortolkning af den »skridtvise tilnærmelse« til »samfundets over- 
flade « fokuserer på i) den voksende mystifikation, som kapitalforholdet og kapitalprocessen undergår gennem de former, som udvikles i cirkulationsanalysen (se især § 47), og ii) partikulariseringen af kapital, som i første omgang udvikles med udviklingen af tre typer fungerende kapital og i anden omgang med den nødvendige betragtning af varens særegenhed som brugsværdi i relation til den totale reproduktionsproces. Denne fremadskridende mystificering og partikularisering giver det begrebslige grundlag for en formanalytisk betragtning af »de forskellige kapitalers vekselvirkning « og »produktionsagenternes sædvanlige bevidsthed «. Sidstnævnte indebærer først den begrebslige udvikling af de vigtigste kategorier for det $\varnothing$ konomiske livs overflade, nemlig privatejendommen, ejendomsretten og personen.

Læsere, som $\varnothing$ nsker at følge denne videre fremstilling henvises til Eldred: Critique of Competitive Freedom and the Bourgeois-Democratic State: Outline of an formanalytic extension of Marx' uncompleted system, publiceret af Kurasje 1984, og Roth, Kleiber, Hanlon og Eldred: La Forma Valore. Progetto di recostruzione del frammento di sistema di Marx, (oversat af $\mathrm{E}$. Agazzi), Manduria 1984.

\section{Kapitalens cirkulationsproces.}

\section{$\S 35$}

Valoriseringsbevægelsen, som blev udviklet i § 23 og yderligere bestemt i § 26 , tages op igen. Denne gang vil det nu blive taget i betragtning, at denne bevægelse kræver tid. Bortset fra produktionstiden, tiden til den materielle produktion af en vareenhed, er der også cirkulationstiden, dvs. den tid, der er nødvendig til cirkulationshandlingerne: til forvandlingen af penge til varer og varer til penge. I løbet af cirkulationsperioden er varer og penge kapitalens iklædning, nemlig henholdsvis varekapital og pengekapital (til forskel fra rentebærende pengekapital i $\S 24-28)$. I løbet af produktionsperioden antager kapitalen skikkelse som produktiv kapital, som produktionsmidler. Faserne som produktiv kapital, varekapital, pengekapital, produktiv kapital ... følger som et resultat af hinanden og konstituerer således faserne i kapitalens kredsl $\phi b$. De andre produktionselementer, arbejdere og jord, trækkes ind i kapitalens kredsløb som nødvendige komplementære elementer til kapitalens eksistens som produktiv kapital. Lejen af arbejdere og jord og betalingen af $l ø n$ og jordrente er efterfølgende cirkulationshandlinger, som komplementerer de først stedfundne værdiforms-forvandlinger af penge til varer og omvendt. Lånet af pengekapital og dens tilbagebetaling sammen med renten tilhører pengekapitalens fase. 
a) Faserne i kapitalens cirkulation introduceres her udfra produktionens synsvinkel. Cirkulationsprocessen er oprindelig bestemt som umiddelbar udvidelse af begrebet om kapitalistisk vareproduktion. Nedenfor ( $\S$ 40ff) vil vi se, at begreberne varekapital og pengekapital, dvs. kapitalens eksistens i cirkulationssfæren, ikke er tilstrækkelig godt karakteriseret. I skikkelsen som cirkulationskapital (\$41) antager kapitalens eksistens i cirkulationssfæren en tilsyneladende uafhængig form. Dette udgør på sin side grundlaget for tildelingen af kapitalfunktioner i hver af dens faser til uafhængige kapitaltyper (\$ 49): industriel kapital, varehandelskapital og pengehandelskapital.

b) Hele cirkulations- og reproduktionsanalysen, som gennemføres i de følgende paragraffer, er uafhængige af arbejdsværditeorien. Det er i særdeleshed ikke forudsat, som Marx gør det i andet bind, at priserne er proportionale med 'arbejdsværdier'. Gennem hele analysen er det et spørgsmål om at rekonstruere en stringent værdiformsanalytisk argumentationsgang, som kan findes hos Marx, men her sammenblandet med en argumentationsgang, der er baseret på den klassiske arbejdsværditeori (jvf. § 4). I begyndelsen af andet bind skriver Marx:

»For at kunne begribe formerne i deres rene skikkelse er det først og fremmest nødvendigt at abstrahere fra alle de momenter, der intet har at gøre med formskifte og formdannelse som sådan. Det antages derfor her, ikke blot at varerne sælges til deres værdi (hvilket er selvindlysende for en værdiformsanalytisk læsning, EHKR), men også at dette sker under uforandrede omstændigheder. Der bliver således også set bort fra de værdiforandringer, der kan indtræde i løbet af kredsløbsprocessen.« (Rh. 2.1., 38; K2, 32. Jvf. $\S \S 44 \mathrm{f}$ i relation til den anden del af denne forudsætning).

Forudsætningen for fremstillingen, nemlig at »varerne sælges til deres værdi« er - indenfor arbejdsværditeoriens argumentationsgang - vigtig for Marx som en indirekte reference til »transformationen af værdier til produktionspriser« i bind 3. At dette emne er overlæsset med problemer kan ses af den omfattende debat om »transformationsproblemet « ${ }^{1}$. Den værdiformsanalytiske kritik af arbejdsværditeorien opløser som en behagelig konsekvens transformationsproblemet, eftersom værdistørrelsen ikke kan bestemmes uafhængigt af værdiformen.

1. Jvf. P. Samuelson, Understanding the marxian notion of exploitation: A summary of the so-called transformation problem between marxian values and competition prices, i: Journal of economic litterature, 9/1971. R. Picard, Wert und Preis in den Marxschen politischen Ökonomie, Erlangen 1974. R. Picard, Zum quantitativen Wertproblem, i: Gesellschaft 3/1975. R. Picard, Gibt es ein Transformationsproblem, i: Gesellschaft 13/1979. D. Foley, The value of money, the value of labour-power and the marxian transformation problem, $\mathrm{i}$ : Review of radical political economi vol. 14, nr. 2, 1982. 


\section{$\S 36$}

Kapitalens tilbagevendende valoriseringsbevægelse indebar kontinuitet $\mathrm{i}$ produktionsprocessen så længe vi så bort fra cirkulationsperioden. Denne kontinuitet bliver afbrudt på dette niveau gennem inddragelsen af cirkulationsperioden i analysen. Der kan nu kun skabes kontinuitet i produktionen ved ikke at betragte kapitalens bevægelse som et enkelt valoriseringskredsløb, men som flere kredsl $\varnothing b$ med en passende faseforskydning, dvs., det er nødvendigt med en deling af kapitalen. Rækkefølgen af kapitalens faser formidles således af en sammenhæng af kapitalsfarer, hvor dele af kapitalen opholder sig i deres bevægelse fra fase til fase. Det antal kredsl $\varnothing b$, som er nødvendige for at formidle kapitalens totale kredsløb med produktionens kontinuitet, afhænger af de enheder i hvilket vareproduktet cirkulerer og af forholdet mellem det enkelte kredsløbs varighed (omslagstiden) og produktionstiden. Produktionstiden defineres som den gennemsnitlige varighed af et vareprodukts ophold i produktionsprocessen. Cirkulationstiden defineres analogt. Produktionstiden og cirkulationstiden taget under ét udgør et kredsløbs varighed, dvs. omslagstiden.

\section{$\S 37$}

Pengekapital-fasen $\mathrm{i}$ et kredsløb kan blive forlænget af den omstændighed, at den produktive fase i et andet kredsløb endnu ikke er afsluttet. Pengekapitalen må således holdes flydende og afvente sin indtræden $\mathrm{i}$ den produktive kapitals fase. Derved opstår der en latensperiode for pengekapitalen, hvor varekapitalen allerede er blevet forvandlet til penge, alle betalinger er blevet foretaget med udbyttet deraf og hvor nye produktionsmidler kunne købes, hvis det ikke var for den kendsgerning, at de endnu ikke er nødvendige i produktionsprocessen. Denne latensperiode i pengeform ville kunne ændres til en latensperiode for den produktive kapital, hvis lagre af råmaterialer osv. blev opbygget. Vi kan tale om en latensperiode for (penge eller produktiv) kapital som opstår pga. delingen af kapitalen ( $\$ 36)$ i en række kredsløb for at skabe kontinuitet i produktionsprocessen. Hvis produktions- og cirkulationsperioderne først defineres uafhængigt af denne latensperiode, dvs. mht. deres længde, når man kun betragter et kapitalkredsløb, og hvis forholdet mellem cirkulationsperioden og produktionsperioden er x, så opstår en latensperiode i den betydning, som er beskrevet her, hvis og kun hvis x ikke er et helt tal. Hvis $x$ er et helt tal, så er antallet af kredsløb givet med $x+1$. Hvis f.eks. $x=2$, så er der tre kapitaldele i tre kredsløb, hvilket kan illustreres som følger: 


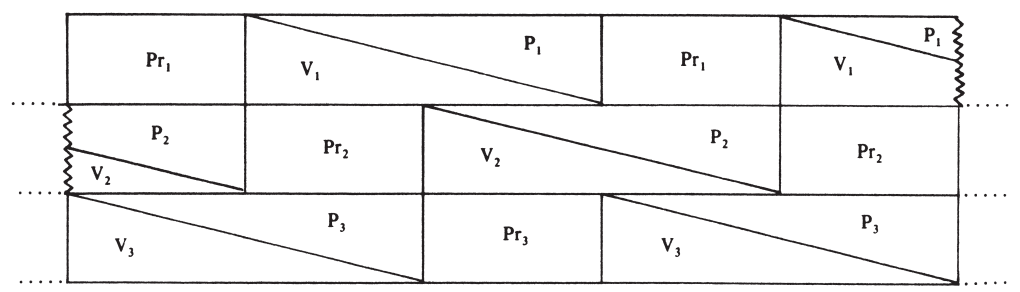

Figur 1

Hvis $\mathrm{x}$ ikke er et helt tal, så er antallet af kredsløb lig med $\overline{\mathrm{x}}+1$, hvor $\overline{\mathrm{x}}$ er det mindste hele tal større end $\mathrm{x}$. Hvis f.eks. $\mathrm{x}=1 \frac{1}{2}$, så er antallet af kredsløb igen lig med 3, og kapitalen ligger latent og afventer sin anvendelse i produktionsprocessen.

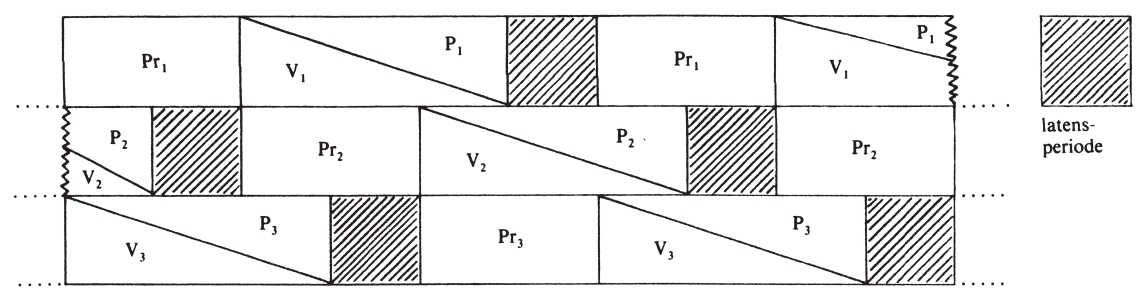

Figur 2

Betydningen af produktionsprocessens kontinuitet vil blive diskuteret i forbindelse med fix-kapitalen (jvf. § 38). Begrænsninger på kapitalens valorisering, som opstår pga. kapitalens eksistens som cirkulationskapital (§ 41) vil blive diskuteret, så snart cirkulationsomkostningerne er blevet introduceret (jvf. $\S \S 42,48$ ).

\section{$\S 38$}

Efter produktionsperioden går hele kapitalen i den produktive fase ikke over i cirkulationsfasen. En del af den produktive kapital, som ikke blev fuldstændigt produktivt konsumeret i produktionsperioden, forbliver i produktionssfæren. Den del af kapitalen, som ikke cirkulerer en bloc med vareproduktet gennem de forskellige kapitalfaser, men kun gradvis, kaldes fix-kapital. Den del af fix-kapitalen som forbliver i produktionssfæren efter en produktionsperiode kaldes hvilende fix-kapital, i modsætning til den del af fix-kapitalen, som cirkulerer med produktet (som gammelværdi, jvf. § 18) og som vi kalder cirkulerende fix-kapital. Den cirkulerende fix-kapital, som er blevet rea- 
liseret i penge, kan ikke umiddelbart indtræde i produktionssfæren igen pga. den ufuldstændige konsumtion af fix-kapitalen. Den forbliver istedet fikseret i pengekapitalfasen som latent kapital og udgør en afskrivningsfond for fixkapital. Svarende til formindskelsen af den hvilende fix-kapital vokser afskrivningsfonden indtil de akkumulerede penge endelig bruges til at erstatte det afskrevne maskineri (eller lignende) i produktionssfæren. Fix-kapitalen komplementeres af den cirkulerende kapital, dvs. den del af kapitalen, som cirkulerer en bloc med vareproduktet. I varekapitalens fase omfatter den cirkulerende kapital gammelværdien af produktionsmidlerne, som er blevet fuldstændig konsumeret i den umiddelbart forudgående produktionsperiode (groft taget rå- og hjælpematerialer) sammen med nyværdien, som er skabt i denne produktionsperiode.

a) Med udviklingen af begrebet om fix-kapital slækkes der på den antagelse, som blev indført i $\S 18$, nemlig at »alle produktionsmidlerne konsumeres i løbet af produktionsprocessen«. Begrebet gammelværdi ( $\$ 18)$, defineret som den værdikomponent af vareproduktet, der dækker udlægget til produktionsmidler, må også modificeres. Arbejdet nedlagt i fix-kapitalen er direkte underlagt værdiformen, når det er købt før det indgår i produktionsprocessen. En yderligere indirekte anerkendelse af dette samme arbejde finder sted hver gang produkter, som er produceret med fix-kapitalen sælges. Salgsprisen er en anerkendelse af arbejde udført med bestemte produktionsmidler, og især med en bestemt fix-kapital. Realiseringen af den cirkulerende fix-kapital i pengeform sker gradvis. På det tidspunkt, hvor fix-kapitalen i produktionsprocessen er blevet konsumeret fuldstændigt, vil der være akkumuleret penge nok i afskrivningsfonden til at erstatte den. Der er ingen måde på hvilken man for hvert omslag præcist kan bestemme andelen af fix-kapitalens gammelværdi i vareprodukternes salgspris. Det er imidlertid almindeligt at fordele gammelværdiens realisering af fix-kapital i pengeform ligeligt over fix-kapitalens totale funktionsperiode (dens 'levetid'). Forskelle mellem ideelle kalkulationer over fix-kapitalens afskrivning og virkelige værdiformsrelationer, der faktisk realiseres, og som en indeholdt i værdiformen selv, vil blive unders $\emptyset \mathrm{gt}$ nedenfor $(\S 44)$.

b) Kapitalens latensperiode er et vigtigt tema i den følgende beskrivelse. Man må skelne mellem to former for latensperiode: materiel og pengemæssig latens. Kapitalens materielle latensperiode (brakliggende produktiv kapital) kan formindskes gennem f.eks. kontinuitet i produktionen (således at fix-kapital ikke temporært er brakliggende). En sådan produktionskontinuitet kræver imidlertid en vis grad af latens for den cirkulerende kapital (la- 
gerlagte råmaterialer), som på sin side kan formindskes gennem at foretage indkøb i faser (oftere, men mindre indkøb). Dette betyder imidlertid blot, at latensperiodens skikkelse delvis er ændret fra materiel til pengeform. Vi har således det paradoksale resultat, at kapitalens valoriseringskredsløb med nødvendighed producerer latent kapital. Specielt betyder dette for penge, at bevægelsen fra penge til flere penge med nødvendighed forudsætter og skaber penge, der ikke umiddelbart deltager i valoriseringsbevægelsen. I $\S$ 46, 48 vil det blive klart, hvorfor enhver latensperiode er en forhindring for kapitalens valorisering. Mens en vis grad af materiel latens (f.eks. usolgte varer) begrænser en individuel kapitals valorisering, så eksisterer derimod den mulighed for latent pengekapital, at den via banksystemet $(\S \S 53,56)$ kan deltage i den samlede samfundsmæssige valorisering.

\section{$\S 39$}

Sondringen mellem fix-kapital og cirkulerende kapital rejser kravet om en nuancering af analysen af, hvorledes kontinuiteten i produktionen opretholdes gennem deling af kapitalen. Hvis produktionen ophører for en periode, så er den hvilende fix-kapital (§ 38) tvunget til at ligge brak. For at starte en produktionsproces kræves der en oprindelig kapital til k $\varnothing \mathrm{b}$ af fix-kapital og cirkulerende kapital til den første produktionsperiode ( $\$ 35)$. Når vareproduktet dukker frem efter denne første produktionsperiode, kræves der en tillagskapital for at holde produktionsprocessen virksom. Denne tillægskapital er mindre end den oprindelige kapital, fordi fix-kapitalen ikke skal erstattes efter en produktionsperiode. Der kan være behov for yderligere tillægskapital afhængig af forholdet mellem cirkulationsperioden og produktionsperioden. Mens vi i $\S 37$ antog, at delingen af kapitalen var en deling i kredsløb af ens størrelse, så kan deres størrelse nu variere. Rækkefølgen af udlæggene kompliceres yderligere, når vi slækker på den antagelse, at kapitalen til en produktionsperiode udlægges på en gang. Cirkulerende kapital, inclusive betaling af lønninger, kan udlægges gradvis i løbet af produktionsprocessen i et antal faser, der afhænger af, hvornår produktionsprocessen fordrer, at særlige midler sættes i sving. Hvis den produktive kapital blev udlagt på en gang, ville det skabe latent kapital i produktiv form. Men som vi bemærkede i $\S 38$ b, er det mere fordelagtigt at have latent kapital i pengeform. Det stykvise udlæg af kapital forstyrrer det simple billede af, at kapitalens deling bestemmes af forholdet mellem produktionsperiode og cirkulationsperiode. I stedet for deles kapital i et antal dele af forskellig størrelse, som må udlægges i en uregelmæssig rækkefølge.

Begrebet oprindelig kapital defineres ikke eksplicit af Marx (jvf. Rh. 2.2, 344; K2, 262). I kapitel 15 »Omslagstidens virkning på kapitaludlæggets 
størrelse« taler han om tillægskapital (Zuschusskapital). Selve kapitlet behandler i detaljer kapitalens deling ( $\$ 36$ ), som nødvendig for kontinuiteten i produktionen under den forudsætning, at hele kapitalen består af cirkulerende kapital (Rh. 2.2, 341; K2, 260). Han gør denne forudsætning, selvom sondringen mellem fix-kapital og cirkulerende kapital indføres i kapitel 8. Vi bruger dette som en begrundelse for at vende rækkefølgen om, i hvilken vi behandler emnerne 'kapitalens deling' (§ 36) og 'fix-kapital' og 'cirkulerende kapital' (§ 38) i forhold til Marx' rækkefølge.

\section{$\S 40$}

Cirkulationssfæren kræver ikke blot tid til, at den valoriserende kapital kan passere igennem den, men den kræver også at lønarbejdere udfører cirkulationsarbejde. Dette arbejde, som er stringent relateret til værdiformens ændring fra penge til vare og omvendt, eller til at etablere eller fastholde lånerelationer uanset type, producerer ingen industrielle varer og er således ikke værdiproducerende, dvs. det er i denne forstand uproduktivt arbejde. Uproduktivt arbejde er ikke desto mindre et nødvendigt tilbehør til produktivt arbejde. Det er arbejde, som altid indebærer omsætning af penge. Lønnen, som betales til cirkulationsarbejderne, er således et fradrag fra merværdien (dvs. det er ikke en del af den nødvendige værdi ( $\$ 14)$, som er skabt i produktionsprocessen).

Transport og oplagring af varer omfatter aktiviteter, der falder i en særlig gruppe i og med, de formidler produktionen af det materielle produkt med dets endegyldige konsumtion. Samtidig er der ikke tale om aktiviteter, der forvandler værdiformen, dvs. køb eller salg, selvom de er intimt forbundne med forvandlingen af værdiformen, varer bliver f.eks. transporteret til dens køber, eller den usolgte vare bliver oplagret indtil dens salg. Man kan betragte spørgsmålet på følgende måde: produktionen af en vare er ikke fuldendt, før den er solgt. Når en vare er solgt, kan salgsprisen includere transport og oplagring af varen. Dette gælder selv hvis varen stadig skal leveres eller oplagres i en periode af den sælgende kapitalist. Arbejdet, som anerkendes i salgsprisen includerer således transport- og oplagringsarbejde udført af den sælgende kapitalist. Selvom de aktiviteter som omfatter transport og oplagring af det producerede produkt, som nu udbydes til salg på markedet, er produktive aktiviteter, så betragtes de som findende sted i cirkulationsperioden for at undgå en dobbelt opregning af cirkulations- og produktionstiden, hvor de overlapper hinanden. Marx skriver om transport-industrien:

»at den fremtræder som fortsættelse af en produktionsproces inden for cirkulationsprocessen og for cirkulationsprocessen«. (Rh. 2.1, 194; K2, 153). 
Køberen kan enten være en kapitalist eller en individuel forbruger. I det sidste tilfælde falder de yderligere processer, som den solgte vare gennemløber, uden for analysefeltet, som udelukkende beskæftiger sig med produktion og cirkulation af kapital. Transport og oplagring, som udføres af private individer er ikke værdiskabende. Når køberen er en kapitalist, så hører arbejde til transport og oplagring af de købte produktionsmidler, når det udføres af den købende kapitalists lønarbejdere, til den købende kapitalists produktionsproces. Hvis cirkulationsmidler købes ( $\$ 41)$, så er deres transport og oplagring uproduktivt arbejde. Forstået på denne måde er transport og oplagring (vare)produktive aktiviteter som »tilføjer et rum-tid indeks til vareproduktionen, dvs. varer må konsumeres og dette kræver transport og dannelse af varebeholdninger «. (Eldred/Roth, 1978, s.95). Den produktive karakter ved dannelsen af en varebeholdning - i modsætning til tilfældet med transporten (jvf. Rh. 2.1, 190ff; K2, 150ff) - behandles ikke entydigt af Marx. På den ene side adskiller Marx oplagringsomkostninger fra rene cirkulationsomkostninger derved, »at de til en vis grad indgår i varernes værdi, altså fordyrer varen«. (Rh. 2.1, 177; K2, 140). Oplagringsarbejdet er nødvendigt for »bevarelsen af varernes værdi « $(\mathrm{Rh} .2 .1,177 ; \mathrm{K} 2,141)$ gennem opretholdelsen af varens brugsværdi. På den anden side argumenterer Marx for, at oplagringsomkostninger, som er et resultat af »den tid, der medgår til at forvandle eksisterende værdier fra vareform til pengeform, dvs. alene har deres oprindelse i en specifik samfundsmæssig form for den samfundsmæssige produktionsproces « (ibid), udelukkende er uproduktive cirkulationsomkostninger. Få sider senere (Rh. 2.1, 189; K2, 149) dukker samme argument op igen, hvor Marx søger at skelne mellem normal og unormal dannelse af varebeholdninger. Normal beholdningsdannelse er den varebeholdning, som er samfundsmæssig nødvendig, selvom arbejdsprodukterne ikke antager vareform. I modsætning hertil finder en unormal beholdningsdannelse kun sted, når varerne ikke kan sælges, dvs. når en eller anden slags overflod opstår. Efter vores opfattelse er denne sondring usammenhængende, fordi den form-ubestemte kategori »varebeholdningsdannelse « $\mathrm{i}$ samfund $\mathrm{i}$ almindelighed ikke kan specificeres. Vi foretager i stedet for en skelnen mellem rene uproduktive cirkulationsomkostninger og oplagring og transport på grundlag af forvandling af vareform til pengeform og omvendt, således at uproduktive aktiviteter og omkostninger altid omfatter omsætningen af penge. Problemet kan ikke afgøres ved at spørge, hvilke omkostninger, der indgår i varens salgspris. Dette er et fuldstændigt udvendigt, begrebsløst profitskabelsesstandpunkt, som også er gyldigt for handelskapital (§ 49), og det er derfor ubrugeligt overfor det forhåndenværende problem. På samme måde er det umuligt at etablere en kategorial forskel mellem en epokal ka- 
tegori (cirkulationsarbejde) og en forestillet transepokal opfattelse af samfundsmæssigt nødvendigt oplagringsarbejde. Dette sidste er ikke baseret på den dagligdags bevidsthed, og kan ikke udvikles fra denne.

Kontinuiteten i produktionen kræver enten, at kapitalisten har et lager af cirkulerende kapital for hånden, eller at han nemt kan skaffe sig det på markedet. En varebeholdning må derfor eksistere i den ene eller anden form, og arbejdet knyttet til at opbygge og vedligeholde denne varebeholdning anerkendes i prisformen, som en integreret del af vareproduktets produktionsproces. Betragtet fra den sælgende kapitalists standpunkt er et lager af varekapital nødvendigt for at sikre kontinuiteten i cirkulationsfasen, f.eks. at være i stand til at opfylde ordrerne, som strømmer ind fra kunderne, hvadenten det er kapitalister eller andre. Selvom arbejdet med transport og dannelse af varebeholdninger er produktivt, dvs. værdidannende, så er det ligesom alt andet produktivt arbejde underlagt værdiformen, og vil under visse omstændigheder ikke opnå anerkendelse eller en anerkendelse, der er utilstrækkelig til at dække omkostningerne. Transport- og oplagringsarbejde kan være forgæves, hvis vareproduktet på trods af dette arbejde forbliver usolgt. Der kan også opstå en anden situation, hvor to varer, som er blevet transporteret over forskellige afstande eller blevet oplagret i forskellige tidsperioder, sælges til samme pris på trods af disse forskelle. Det yderligere transporteller oplagringsarbejde opnår i dette tilfælde ikke en supplerende værdiformsanerkendelse. Den produktive karakter ved vareoplagring og transport må ses i modsætning til den ikkeproduktive karakter ved oplagringen, transporten og omsætningen af penge, hvilket altsammen hører strikte til cirkulationsarbejdet.

\section{$\S 41$}

Cirkulationssfæren kræver ikke blot cirkulationsarbejde (§ 40), men også udlæg af kapital til cirkulationsmidler, dvs. til industrielle varer, som er nødvendige for udførelsen af cirkulationsarbejdet. Disse cirkulationsmidler falder i lighed med produktionsmidlerne i to kategorier: fix-cirkulationskapital (f.eks. varehuse, computere), som fungerer i adskillige omslagsperioder for cirkulationskapitalens individuelle kredsløb; og cirkulerende cirkulationskapital (f.eks. kontormaterialer, lys), som konsumeres i løbet af en vareenheds vej gennem cirkulationssfæren. Som en konsekvens af diskontinuiteten i produktionskapitalens eksistens i cirkulationssfæren (§37) må cirkulations-kapitalen og især fix-cirkulationskapitalen med mellemrum ligge brak i materiel form (f.eks. uudnyttet kapacitet i varehusene, uudnyttet computerkapacitet, underbeskæftigede kontorarbejdere). Analogt til cirkulationsarbejdet er den cirkulationskapital uproduktiv, som egentlig ikke cirkulerer 
i et værdikredsl $\varnothing b$, fordi den udlagte værdi konsumeres i cirkulationssfæren uden at forøge værdidannelsen. Cirkulationskapitalen genvindes kun som en bestanddel af vareproduktets merværdi. I modsætning til produktionskapitalen, som udlægges i produktionssfæren og som passerer igennem cirkulationssfæren i dens valoriseringsbevægelse, opsuges cirkulationskapitalens værdi af cirkulationssfæren uden at efterlade sig et spor.

Der er her tale om en dobbelt brug af terminologi. Cirkulationsmidler, som de er defineret her, må ikke forveksles med penge som cirkulationsmidler $(\S 9)$.

\section{$\S 42$}

Med cirkulationskapitalen er begrebet om omkostninger ( $\$ 23$ ) udvidet til at omfatte udlægget til cirkulationsmidler og betaling for cirkulationsarbejde, for jordrenten på den jord, som anvendes til cirkulationsaktiviteterne såvel som til renten af den lånte cirkulationskapital. I tillæg til de produktive kapitalomkostninger må alle disse omkostninger fradrages fra vareproduktets værdi som cirkulationsomkostninger, hvilket efterlader en reduceret overskydende virksomhedsprofit. Dette udvidede omkostningsbegreb mystificerer yderligere valoriseringen af kapitalen gennem udbytning af arbejdskraft ved også at includere kapital, som ikke har nogen egentlig cirkulær bevægelse og arbejde som ikke skaber værdi. Et yderligere trin i udvendiggørelsen af kapitalens bevægelse fra værdidannelsesprocessen og et yderligere trin i den deraf følgende mystifikation af værdidannelsesprocessen opstår i og med, at kapital ikke blot udlægges til køb af produktions- og cirkulationsmidler, men også til betaling af lønninger, jordrente og rente, dvs. til betaling af revenuer. Dette sker i tilfælde, hvor den fastsatte dato for betalingen af revenuerne indtræder før den udlagte kapital vender tilbage fra salget af produktet og således muliggør, at betalingerne kan ske ud af indtægterne. Adskillelsen mellem betaling og udlæg bliver udvisket. Kapitalens kredsløbslignende bevægelse opløses i et virvar af betalinger og indtægter på alle mulige tidspunkter. Omkostninger, som er pådraget på et tidspunkt, dækkes gennem indtægter på et senere tidspunkt. Kapitalkredsløbenes valoriseringsbevægelse udvendiggøres i en mængde omkostningskredsløb, som periodisk udlignes gennem indtægter. Denne udvendiggørelse af kapitalbegrebet begyndte allerede med bestemmelsen af valoriseringen som salgsprisens overskud i forhold til omkostningerne (§ 23). Nu er der imidlertid selv dele af merværdien, nemlig udlæggene til revenu og cirkulationskapital, som er blevet kapitaludlæg og således tilsyneladende valoriserende kapital. Begrebet om omslag (§ 36) er således 
modificeret (og udvendiggjort) til at omfatte perioden mellem udlægget og tilbagekomsten af dele af kapitalens omkostninger. Eftersom omkostningskredsl $\varnothing$ bet ikke nødvendigvis svarer til den valoriserende værdis kredsl $\varnothing b$, er omslaget defineret som tiden mellem udlægget og tilbagekomsten af indtægterne fra det produkt, som den (i tilfældet med cirkulationskapitalen) hjælper med at cirkulere, eller af hvilket den (i tilfældet med produktionskapitalen) udgør en værdibestanddel. Omslaget for udlægget til revenuomkostninger bestemmes af tiden fra udlægget af kapital til tilbagekomsten af indtægterne fra det produkt, hvis produktion og cirkulation medførte omkostningerne, som blev udlagt. Hvis færre omkostninger beregnes dækket af indtægterne, så er virksomhedsprofitten større, men omslagstiden for den udlagte kapital er dermed blevet tilsvarende længere.

Omslagsbegrebet er nu kompliceret af mængden af udlæg, der foretages, og af udlæggets art (til produktionskapital eller til betaling af revenu). Omslagsperioden, for den totale fungerende kapital (oprindelig og tillægskapital) (§ 43) som anvendes, bestemmes ved at integrere omslagstiden for hvert enkelt udlæg og sammenvejning af hver af disse omslagstider i forhold til udlæggets størrelse. Dette giver begrebet aggregeret omslagstid.

\section{$\S 43$}

Begreberne oprindelig kapital og tillaggskapital (§ 39) er nu udvidet til ikke kun at dække produktionskapital, men også cirkulationskapital og udlæg foretaget til revenubetalinger. I stedet for at være et antal af den valoriserende værdis kredsløb bliver kapitalens bevægelse dermed en mængde udlæg til forskellige omkostninger og generhvervelsen af disse omkostninger plus en virksomhedsprofit. Salget af vareproduktet vedbliver at være det punkt fra hvilket indtægterne flyder til kapitalisterne. Den oprindelige kapital vedbliver at være den fixe og cirkulerende produktionskapital, som er nødvendig for at sætte produktionsprocessen i bevægelse. Tillægskapital er nødvendig 1) for at erstatte den cirkulerende produktionskapital efter at den har bevæget sig ind i cirkulationssfæren, 2) som (fix og cirkulerende) cirkulationskapital, 3) til betaling af revenuer (når den fastsatte betalingsdato falder før tilstrækkelige indtægter er akkumuleret fra salg af produktet), 4) til tilbagebetaling af lånekapitalen (når tilbagebetalingsdatoen falder før kapitalen er vendt tilbage gennem indtægter fra salget), og 5) til erstatning af den fixe kapital in natura efter den sidste bestanddel af den fixe (produktions eller cirkulations) kapital er blevet konsumeret, således at kontinuiteten i produktions-og cirkulationsarbejdet kan opretholdes, selvom omkostningerne til den sidste bestanddel af fix-kapitalen endnu ikke er blevet dækket 
ind af kapitalens cirkulære bevægelse. Summen af den oprindelige kapital plus alle tillægskapitalerne bestemmer størrelsen af den valoriserende kapital, eller den fungerende kapital. Sondringen mellem oprindelig kapital og tillægskapital gør det klart, hvilke yderligere omkostninger en ny kapital må regne med, hvis valoriseringen af den i første omgang udlagte kapital skal gennemføres. Tillægsomkostningerne kræver på den anden side yderligere udlæg, hvilket gør kapitalens valoriseringsproces til en vedvarende proces, som i sig selv ikke har nogen slutning.

\section{$\S 44$}

Begrebet omslag ( $(42)$ opstår i forbindelse med en vedvarende kapitalvaloriseringsproces i hvilken fungerende kapital anvendes igen og igen i gentagne kredsløb med udlæg og dækning af omkostninger. I denne cirkulære bevægelse i tiden kan værdiformsanerkendelsen af det vareproducerende arbejde i penge såvel som priserne for de andre produktionselementer ændres. Kapitaludlægget til produktionsmidler generhverves som en del af produktværdien som gammelværdi ( $§ 18)$. Den oprindelige udlagte værdistørrelse kan meget vel være forskellig fra den aktuelle genanskaffelsespris for produktionsmidlerne, som må dækkes af produktværdien, hvis et nyt kredsløb skal kunne påbegyndes. I løbet af den tid, som det tog den udlagte produktionskapital at slå om, kan priserne for disse produktionsmidler være steget eller faldet. Fungerende kapital er således enten frisat fra kredsløbet - i tilfælde af prisfald - eller der er brug for tillægskapital til at financiere de forøgede omkostninger til produktionsmidler. Vi forudsætter her at enhver tillægskapital, som er nødvendig, hidrører fra salgsindtægterne af produkterne fra det foregående kredsløb. Gammelværdien, som nu defineres som den værdibestanddel af produktet, som er lig med den aktuelle genanskaffelsespris for produktionsmidlerne (jvf. § 18b), kan derfor adskille sig fra den kapitalværdi, som oprindeligt blev udlagt til produktionsmidler. Kapitalens omslag kan ikke begribes som en proces i hvilken værdien automatisk bevarer og forøger sig selv, men som en proces i hvilken vedligeholdelsen af værdien over tiden drages i tvivl gennem tilfældigheden i vareudvekslingsprocessen. Målet at forøge værdien kan blive fuldstændig forpurret, hvis det ikke lykkes en udlagt værdi at vedligeholde sig selv henover dens omslag. Problemet med den udlagte produktionskapital-værdis afvigelse fra gammelværdien i løbet af omslaget er så meget desto mere markant for den fixe produktionskapital hvor omslagsperioden er længere. Den udlagte fix-kapital slår gradvis om i løbet af hvert af den cirkulerende kapitals kredsløb. Omfanget af dette gradvise omslag kan ikke fastsættes præcist, og må således baseres på en kalkulation, i hvilken det gradvis stigende omslag antages at foregå ensartet henover den formodede 
levetid for den fixe kapital. Alle disse kalkulationer viser sig at være nytteløse, hvis prisen for de fixe kapitalproduktionsmidler i mellemtiden ændrer sig, eller hvis den passende fix-kapital, som må genanskaffes, afviger markant fra den fix-kapital, som netop er konsumeret. Den kontinuerte omvæltning af produktionsmetoderne, og den følgende ændring i værdirelationerne, gør sig specielt stærkt gældende for den fixe kapital, hvor dens fixering af kapitalen i materiel form forhindrer dens opdatering.

\section{$\S 45$}

I analysen af den kapitalistiske produktion ( $\S 14 \mathrm{ff})$ blev der afdækket en systematisk grund til, at priserne på produktionsmidlerne ikke forblev konstant, nemlig forøgelsen i produktiviteten i forbindelse med den relative merværdiproduktion. Dette medfører, at de produktionsmidler, som skal genanskaffes til et nyt kapitalkredsløb (og dette er specielt tilfældet med den fixe kapital), ændrer sig 1) i sammensætning og 2) i pris. Ændring i sammensætningen af de produktionsmidler, som er nødvendige (til en mere produktiv produktionsproces), medfører, at den gammelværdi, som skal udvindes af produktværdien for det næste kredsløb, ændrer sig. Det er her ikke længere et spørgsmål om prisændringer på produktionsmidler af samme slags, men om ændringer i selve produktionsmidlerne - og følgelig en ændring i mængden af produktiv kapital, som er nødvendig. Et yderligere problem opstår, når en forøgelse i produktiviteten truer bevarelsen af værdien, som er udlagt til produktionsmidler. Forøgelser i produktiviteten fører generelt til et fald i enhedsprisen på den producerede vare. Hvis en kapital opererer med gammeldags produktionsmidler - i særdeleshed med forældet fix-kapital - så vil dens enhedsomkostninger være højere end for en kapital, der arbejder med nyere og mere produktive produktionsmidler. Hvis den nye produktionsmetode er blevet almindelig og har ført til et fald i enhedsprisen på vareproduktet, så trues omslaget på de forældede produktionsmidler (specielt fix-kapital). Enhedsomkostningerne er for høje til at blive dækket ind af den reducerede salgspris pr. styk. Kapitalen hører op med at valorisere og tillægskapital må fremskaffes fra eksterne kilder for at financiere en ændring i protuktionsmetoden. Den gamle fixkapital må afskrives, som uproduktiv, da den ikke bidrager til skabelsen af virksomhedsprofit under de ændrede værdiformsrelationer og dens omslag bliver brat afskåret. På den anden side er eksistensen af fix-kapital i produktionsprocessen en hindring for indføring af nye, mere produktive produktionsmetoder, som kræver nyt maskineri. En kapitalist vil først anvende en ny produktionsmetode, når hans fixkapital er slået om og således akkumuleret $i$ en afskrivningsfond, der er tilstrækkelig til at dække det nye udlæg til fix- 
kapital. Kun hvis enhedsprisen på produktet er blevet væsentligt reduceret, vil kapitalisten blive tvunget til at afskaffe sin fix-kapital. Anvendelsen af en ny produktionsmetode, som involverer ny fix-kapital, tenderer således mod at finde sted i bølger, som svarer til omslaget for den fixe kapital. Det lykkes for nogle kapitaler først at anvende ny fix-kapital, efter at den gamle er slået succesfyldt om. Andre kapitaler, som ligger bagefter i den fixe kapitals omslag, må enten ophøre med at operere eller afskrive gammel fix-kapital, selvom det endnu ikke er nedslidt.

a) En tilsvarende argumentationslinie kan udvikles for ændringer i priserne på cirkulationsmidler og specielt for omslaget af den fixe cirkulationskapital. Forskellen er, at man ikke har noget begreb om gammel-værdi, som måler succes eller fiasko i bevarelsen af værdien i løbet af omslaget for en udlagt kapital.

b) Kozo Uno har følgende kommentar til de forhindringer for væksten i produktiviteten, som ligger i den fixe kapital:

»Fordi fix kapital udstyr, når man først har investeret i det, må bruges over et spån på adskillige år, så kan en ny produktionsmetode i mellemtiden ikke let fortrænge den gamle metode, som er indeholdt deri ... Den generelle anvendelse af nye produktive metoder må derfor i princippet påtvinges kapitalen af konkurrencens alvor, som den står overfor i faser med industriel krise. (Kozo Uno, Principles of political economy: Theory of a purely capitalist society, Harvester, Sussex 1980, s. 53.)

Henvisningen til konkurrencen hér er et fingerpeg om, at på dette trin $\mathrm{i}$ fremstillingen er der strengt taget tale om en foregribelse, hvis man taler om erstatningen af fix-kapital under konkurrencens tvang. En nærmere unders $\varnothing-$ gelse af den konkurrencesatte subjektivitet og af konkurrencebetingelserne kan findes hos Eldred, 1984, del II og III.

\section{$\S 46$}

Kapitalens valoriseringsproces fremstiller sig som en række af udlæg og afkast. Den kvantitative bestemmelse af denne bevægelse kræver, at yderligere ét moment tages i betragtning: tiden.

Overskuddet (virksomhedsprofitten) er ikke længere forskellen i én enkelt bevægelse P-P', men realiseres kontinuert gennem indtægten fra salget af vareproduktet. Den kvantitative bestemmelse af overskuddet er kun mulig, når en bestemt tidsperiode forudsættes. Traditionelt anvendes en tidsperiode på ét år til sådanne kalkulationer. Overskuddet pr. år sættes i relation til den fungerende kapital (§ 43). 
Begreberne oprindelig kapital og tillægskapital modificeres igen m.h.p. at tage hensyn til tidsenheden på ét år.

Oprindelig årlig kapital betegner den kapital, som i begyndelsen af regnskabsåret (hvor produktionsprocessen allerede kan være i gang) forefindes enten i materiel skikkelse som fix eller cirkulerende kapital eller som pengesummer i kapitalisternes hænder. Årlig tillagsskapital er den tillægskapital, som i løbet af året er nødvendig for at fastholde valoriseringens kontinuitet eller til at udvide valoriseringsprocessen. I den kvantitative bestemmelse af den fungerende kapital anvendes også ét år som kalkulationsperiode, hvor så de forskellige udlæg vægtes svarende til den tid, de befinder sig i produktions-og/eller cirkulationssfæren, dvs. svarende til længden af deres omslagstid (\$ 42).

Den årlige fungerende kapital er den gennemsnitlige kapitalstørrelse, som udlægges eller som er ledig i kapitalistens hænder i cirkulations- og produktionssfæren. Eftersom vi antager, at al pengekapital er udlånt, svarer den fungerende kapital til den gennemsnitlige kapitalstørrelse, som er udlånt gennem året. Den årlige virksomhedsprofit er den totale årlige indtægt fra salget af vareproduktet fratrukket de totale årlige omkostninger (hidrørende fra årets $k \varnothing b$ af produktions- og cirkulationsmidler samt fra årets betalinger af revenuer). Den årlige nettoprofitrate er forholdet mellem den årlige virksomhedsprofit og den årlige fungerende kapital. Hvis der i løbet af året er foretaget betydelige udlæg af fix-kapital (produktions- eller cirkulationskapital), vil den årlige virksomhedsprofit blive negativ. Af kalkulationshensyn afskrives den fixe kapital over en årrække, i hvilken den fungerer i cirkulations- eller produktionssfæren. De fixe kapitalomkostninger bliver da fordelt over en årrække.

Marx foretager en tilsvarende distinktion mellem fungerende kapital og anvendt kapital i bd. II, kap. 16. Eftersom en årlig fungerende, cirkulerende kapital kan slå om adskillige gange på et år, kan den afvige fra den totale anvendte kapital i løbet af året. Jo hurtigere kapitalomslag, jo mere merværdi produceres pr. år af en fungerende kapital af en given størrelse. Marx' diskussion centrerer sig om »den variable kapital «, som er udlagt til køb af arbejdskraft, eftersom han af arbejdsprocessens elementer isolerer det levende arbejds som merværdiens kilde. Dette gør tillige forudsætningen om en konstant merværdirate plausibel, eftersom konstansen blot kræver faste lønninger (i henhold til arbejdsværditeorien). Vores rekonstruktion af begrebet om relativ merværdiproduktion skulle gøre det klart, at det - for det udviklede begreb om relativ merværdiproduktion (\$20) - ikke er meningsfuldt fortsat at betragte arbejdskraften isoleret fra de objektive produktionsfakto- 
rer, hvorfor endvidere forudsætningen om en ensartet merværdirate ej heller kan forsvares, så snart begrebet om relativ merværdiproduktion er udviklet.

Ikke desto mindre holder følgende resultat: Alt andet lige er den virksomhedsprofit, som afkastes af en fungerende kapital af en given størrelse, omvendt proportional med dens omslagstid. En kortere omslagstid muliggør en accellereret valorisering.

\section{$\S 47$}

Med begreberne årlig virksomhedsprofit og årlig nettoprofitrate (§ 46) er kapitalens bevægelse som en proces blevet totalt mystificeret. Ikke alene er de totale omkostninger blevet samlet under én hat, hvorved distinktionen mellem de forskellige produktions- og cirkulationselementer er forsvundet; men også kapitalens egen cirkulære bevægelse, værdiens fremadskriden gennem dens forskellige stadier som kapital, er tilsløret. På dette sted korresponderer kapitalbegrebet med dét, som optræder i kapitalistisk bogholderi, dvs. med en aldeles formel, udvendig definition af kapital, i hvilken alle indre forbindelser er blevet udslettet. Især er relationen kapital - lønarbejde og dens iboende værdiskabende funktion i valoriseringen af værdi blevet skjult i mangfoldigheden af omkostninger.

Kapitalrelationens fetischisme viser sig på dette sted i fremstillingen som en mangfoldighed af faktorer, som må tages i betragtning ved bedømmelsen af en given kapitals valoriseringseffektivitet.

Eftersom den indre forbindelse mellem disse faktorer - konstitueret gennem værdikategorierne - forsvinder i kapitalistens omkostnings- og profitkalkulationer, da tillægges de alle samme betydning. Til den praktiske aktivitet $\mathrm{i}$ virksomheden behøves ingen indsigt $\mathrm{i}$ indre begrebslige relationer.

\section{$\S 48$}

Den årlige nettoprofitrate er bestemt af to størrelser: i) årlig virksomhedsprofit og ii) årlig fungerende kapital.

Ad i): Den årlige virksomhedsprofit afhænger af forskellen mellem produktets salgspris og de totale omkostninger. Er salgsprisen pr. enhed fast (markedspris), kan den årlige virksomhedsprofit øges gennem sænkning af omkostningerne (mere favorable indkøbspriser, rente og løn, større produktivitet, større effektivitet i cirkulationsarbejdet, fuld udnyttelse af produktions- og cirkulationskapaciteten) og gennem hurtigere omslag, dvs. gennem en kortere produktions- og/eller cirkulationstid, så den samme kapital kan slå om flere gange på et år. Dette gælder både produktions- og cirkulationskapital. 
Ad ii): Den årlige fungerende kapital kan reduceres ved at sænke omkostningerne og ved at $\emptyset$ ge omslagshastigheden. Tilsvarende kan en fungerende kapital af en given størrelse anvendes til at frembringe flere produkter og større virksomhedsprofit, såfremt enhedsomkostningerne og/eller omslagstiden mindskes.

De forskellige metoder til at reducere den årlige fungerende kapital (i.f.t. et givent produktionsomfang) eller $\emptyset$ ge den årlige virksomhedsprofit kan komme i konflikt med hinanden. F.eks. kan virkningen af en stigning i produktiviteten, som indebærer en forøgelse af produktionens omfang, blive ophævet af en forøgelse i cirkulationstiden (såfremt nye markeder ikke kan findes til merproduktionen).

\section{$\S 49$}

Som vist i den foregående paragraf afhænger valoriseringen af kapital af omkostningerne og produktionens og cirkulationens hastighed. Kapitalens valoriseringsproces formidles af en række autonome kapitalskikkelser, hvilket nu skal undersøges. Dét, som vi hidtil blot har betegnet kapital, skal fra dette punkt i vores fremstilling betegnes grundkapital. Kapital, som anvendes til vareproduktion, betegnes industriel kapital, medens kapital, som anvendes til udførelsen af cirkulationsarbejde, betegnes kommerciel kapital (eller handelskapital).

Da cirkulationssfæren omfatter både varekapitalens og pengekapitalens aktivitetssfærer (§ 35f), kan kommerciel kapital yderligere opdeles i varehandelskapital (købmandskapital) og pengehandels-kapital.

Industriel kapital er hovedsagelig anlagt i produktionssfæren, men omfatter også begge stadier i cirkulationen - omend i forkortet form.

De to stadier i cirkulationen konstituerer aktivitetssfæren for de to typer af kommerciel kapital. Eftersom industriel kapital omfatter alle stadier, så er det dén af de tre kapitaltyper, hvis kredsløb mest ligner grundkapitalens kredsløb.

Varehandelskapital, der ligesom enhver anden kapital er indeholdt i den abstrakte formel P-P', er hovedsagelig anlagt i varekapitalens sfære, men med køb og salg træder den også ind i pengekapitalens sfære. Pengehandelskapitalen er væsentligst begrænset til pengekapitalens sfære og formidler sammenfletningen af industriel kapital og varehandelskapital ved at udføre deres monetære transaktioner. Betalingen af revenu, oplagringen af ledige penge samt administrationen af pengekapitalens udlån (se diskussionen af banker nedenfor $\S \S 51 \mathrm{ff}$ ) udføres også af pengehandelskapital. Opsplitningen af grundkapitalen og formidlingen af dens bevægelse v.h.a. tre gensidigt autonome, men indbyrdes afhængige partielle bevægelser medfører - på grund af denne specialisering - en forøgelse af omslagshastigheden (for de betragtede varer), 
en sænkning af omkostningerne, og - især -en reduktion af ledig cirkulationskapital. Reduktionen fremkommer, fordi kommerciel kapital formidler såvel varesalg som monetære transaktioner for mere end én industriel kapital.

Marx skelner ikke begrebsligt mellem »kapitalens grundform« (Rh. 1, 267; K1, 178) og industriel kapital, men behandler dem synonymt. Han udvikler de afledede kapitalformer i kapitlerne om kommerciel kapital i 3. bind, 4. afsnit efter behandlingen af gennemsnitsprofitraten og dens angivelige tendens til fald. Gennemsnitsprofitraten er imidlertid uden tvivl et tema for konkurrenceanalysen (se Eldred 1984, § 31), eftersom konkurrence mellem kapitaler må introduceres for at forklare tendensen til nivellering af den årlige nettoprofitrate. De tre specialiserede kapitaltypers formidling af grundkapitalens bevægelse er derimod et tema, som falder ind under behandlingen af kapitalens cirkulationsproces. De tre kvalitativt forskellige kapitaltyper opstår organisk ud af betragtningen af de forskellige kapitalstadier, dvs. uafhængig af enhver unders $\emptyset$ gelse af profitratens kvantitative bestemthed.

\section{$\S 50$}

Industriel kapital, varehandelskapital og pengehandelskapital er det samme for så vidt det med disse, som med grundkapital, drejer sig om valorisering af udlagte penge. Bestemmelserne af grundkapitalens valorisering kan med passende modifikationer overføres til de nævnte kapitaltyper. De tre typer af fungerende kapital formidler grundkapitalens valoriseringsproces og tager del i den gennem valoriseringen af hver udlagt kapital. Varehandelskapitalens tagen del fremkommer i prisdannelsen mellem industriel kapital og varehandelskapital. Varehandelskapitalens profit er forskellen mellem varernes købspris og salgspris fratrukket cirkulationsomkostninger.

Denne afvigelse mellem købspris og salgspris, som fremkommer gennem tillæg af en profitmargin til købsprisen, bekræfter den naive bevidstheds falske forståelse, at vareprisen simpelthen er summen af omkostningerne med tillæg af en mark-up. Rent faktisk udtrykker varens mellemliggende salgspris ikke varens værdi, men omkostningerne samt den sælgende industrielle kapitals profit. Realiseringen af vareværdien sker først i den endelige (detail-) pris. De mellemliggende priser er blot krav på en del af den endelige realiserede vareværdi. For den sælgende industrielle kapitals vedkommende bliver disse krav umiddelbart tilfredsstillet mod afståelse af en del af den forventede profit, mens det for den kommercielle kapital gælder, at disse krav -som omkostninger - først realiseres i det endelige salg. På dette fremstillingsniveau fremstår den industrielle 
profit som kapitalomkostninger, som endnu ikke er realiseret. Den vertikale opsplitning af grundkapitalen indebærer en vertikal strukturering af varemarkedet, hvilket ikke kun gør kapitalbegrebet, men også prisbegrebet mere overfladisk.

Med distinktionen mellem industriel kapital, varehandelskapital og pengehandelskapital bliver kapitalens saregenhed (partikularitet) for første gang emne $\mathrm{i}$ fremstillingen. Denne sœregenhed beror ikke på den producerede vares materielle særegenhed, som først får betydning senere i fremstillingen (se $\S \S 57 \mathrm{ff}$ ). Det er derfor stadig muligt at overføre alle begrebslige bestemmelser, som er fremkommet i udviklingen af det almene kapitalbegreb (som i sidste ende førte til et overfladisk kapitalbegreb), til de tre ovennævnte kapitaltyper. Samtidig indeholder denne differentiering af grundkapital imidlertid et vigtigt moment, som vil lede fremstillingen videre. Dette moment er referencen til kapitalkredsløbets samfundsmæssige sammenhæng. Hidtil er kapitalen og dens valorisering blevet behandlet som noget enkeltstående og autonomt. Denne undertrykkelse af kapitalens samfundsmæssige aspekt hidrører fra værdibegrebet selv, idet netop dette begreb abstraherer fra særegenheden (se § 4) og således fra den rolle, dette moment spiller i den samfundsmæssige reproduktionsproces. Materiel reproduktion er hidtil blevet taget for givet. Denne forudsætning vil blive ophævet i den videre fremstilling ( $\S 57 \mathrm{ff}$ ), og dette kræver, at kapitalernes særegenhed bliver taget i betragtning.

På dette sted skal mindes om, at vi begyndte med de mange vareproducenter og deres enshed i kapitalbegrebet. Med absolut og relativ merværdiproduktion opstod differentieringer, som satte deres præg på produktionsprocessens konkrete skikkelse. Varens særegenhed forblev imidlertid uden betydning. Vareproducenten blev individualiseret som de mange kapitaler i en branche. Denne individualisering gjaldt alle vareproducenter og var derfor en almen bestemmelse. På samme måde gælder alle foranstående bestemmelser af kapital for alle individuelle kapitaler i en branche. Kapitalbegrebet bliver dermed udviklet, men forbliver alment, da de yderligere bestemmelser ikke beror på varens særegenhed. De videre bestemmelser af kapitalbegrebet berører således ikke dets almene gyldighed, men adskiller sig ikke desto mindre fra den tidligere begrebslige udvikling. Dette hænger sammen med, at kapitaler ikke længere undersøges som om de var autonome, men i stedet bliver den indbyrdes afhængighed mellem de tre kapitaltyper, som formidler grundkapitalens kredsløb, bragt i forgrunden. Hvad angår kommerciel kapital er denne formidling ikke begrænset til en individuel grundkapital, men omfatter flere. Med begrebet kommerciel kapital (som omfatter både købmandsog bankkapital) bliver grundkapitalerne, som her optræder i forkortet form som industrielle kapitaler, bundet til hinanden i deres kredsløb. Fremfor alt 
er det banksystemets almenhed ( $\S$ 51ff) og dets almene vare, lånekapital, som understreger de individuelle kapitalers indbyrdes afhængighed, eftersom banksystemet fungerer som akkumulationsstedet for pengekapital, som siden stilles til rådighed for de talrige individuelle fungerende kapitaler.

\section{$\S 51$}

Pengehandelskapitalen udfører de forfaldne betalinger, opbevarer ledig kapital og administrerer lånerelationer for de fungerende kapitaler. For disse funktioner modtager den virksomhedsprofit. Administrationen af lånerelationer skal nu undersøges nærmere.

Opbevaringen af store mængder ledig pengekapital tilhørende de fungerende kapitaler og andre indskydere, gør det muligt for pengehandelskapitalisten at udlåne disse indskud til trediepersoner som rentebærende kapital uden at forstyrre de indskydende fungerende kapitalers valoriseringsproces. Vi har tidligere set ( $\$ 38)$, at ledig pengekapital er et nødvendigt biprodukt til valoriseringsprocessen, især som ledig fix-pengekapital, som gradvist akkumuleres i en afskrivningsfond. En anden kilde til ledig pengekapital er den akkumulerede virksomhedsprofit, som den fungerende kapitalist i sidste instans kan anvende til at ekspandere produktionens omfang. Ved at udlåne pengekapital fremstår pengehandelskapitalen for udenforstående som rentebærende pengekapital og bliver derigennem i systematisk forstand en bank. Den rente, som banken modtager for udlånte penge, deles mellem banken og indskyderne (som ikke nødvendigvis kun behøver at være fungerende kapitalister). Eftersom det i en vis udstrækning er umuligt at afgøre hvis penge, som er genudlånt, opnår enhver indskyder rente af indskuddet. Ledig kapital, som koster den lånende fungerende kapitalist en rente, bliver som indskud rentebærende for den indskydende fungerende kapitalist. Differencen mellem den rente, som banken modtager for udlån og rente, som banken betaler indskyderne, konstituerer størsteparten af bankens virksomhedsprofit og bestemmer derigennem valoriseringen af bankens fungerende kapital. Der må skelnes skarpt mellem denne fungerende kapital og den i banken indskudte kapital. Bankens fungerende kapital består af fixe kapitalomkostninger (bankbygning, computer, bokse, alarmsystemer etc.) og cirkulerende kapital (papir, formularer og, især, løn til bankpersonalet). Udover jordrente og rente af lånt fungerende kapital er det især renteudbetalinger på indskud, der fremstår som omkostninger. Rentebetalinger på indskud kan sammenlignes med de priser, som en varehandelskapital må betale for varer (som fremstår som cirkulerende kapitalomkostninger for varehandelskapitalen). Forskellen er, at den vare, som banken handler med, er pengenes egenskab i henseende til at blive udlagt som kapital ( $\$ 24)$. Banken køber denne egenskab billigt og sælger den dyrere. 
Eftersom banken er en fungerende kapitalist (med pengekapitalistens maske), der i lighed med alle fungerende kapitalister arbejder med lånte penge (denne forudsætning vil blive slækket i konkurrenceanalysen), opstår spørgsmålet hvorfra banken låner dens fungerende pengekapital. I princippet kan den låne af sig selv, ud af de indskudte penge. (Endvidere kan den skabe sin egen fungerende pengekapital; se $\S 56$ ). Distinktionen mellem indskudte penge og fungerende kapital svarer til bankens dobbelte bestemmelse som udlånende pengekapitalist og pengehandelskapitalist. Denne fordobling af banken er fordelagtig, eftersom banken selv sparer forskellen mellem renten på bankkredit (§ 53) og renten på indskud. Uanset denne fordel må banken sikre, at den er i stand til at tilbagebetale indskud svarende til de betingelser, under hvilke de blev indskudt.

\section{$\S 52$}

Enhver indskyder ( $§ 51)$ har en bankkonto, som har en bestemt (for det meste rentebærende) saldo. Disse saldi repræsenterer giropenge, som skal skelnes fra den eneste type penge ( $\$ 9 \mathrm{a})$, som er udviklet hidtil, nemlig guldpenge ( $\S 6$ ff). Guldpenge besidder de bestemmelser, som fremkom i analysen af penge og varer (§ 9), nemlig cirkulationsmiddel, værdimål, absolut værdi og betalingsmiddel ( $\$ 11)$. Heroverfor fungerer giropenge kun som cirkulationsmiddel og betalingsmiddel og får sit mål fra guldpenge. Giropenge er derfor en pengetype, som er udviklet af varepenge. Indskyderen disponerer over sin saldo ved at give banken instruktioner, ved hjælp af hvilke indskyderen kan i) omdanne kontanter til giropenge (indskud); ii) Overfore giropenge fra hans/ hendes konto til en anden; iii) Omdanne giropenge til kontanter (udtraek). Udtrækkene kan foretages ved hjælp af cheks, som i den tid, der går førend banken får checken, kan passere fra hånd til hånd og på denne måde fungere som cirkulations- og/eller betalingsmiddel. Checken er simpelthen giropengenes repræsentant udenfor banken, deres dualis så at sige.

\section{$\S 53$}

Kapitalerne tilbagebetaler pengekapital, som er vendt tilbage og som truer med at ligge brak, til udlåneren. Dette er kun muligt, hvis kapitalerne atter kan finde passende lånekapital, når de behøver det. Kun da kan den årlige nettoprofitrate blive forøget ved tilbagebetaling af lånekapital gennem besparelser på renteomkostninger og gennem reduktion af den fungerende kapitals størrelse. For den udlånende pengekapitalist betyder tilbagebetalingen af pengekapital rentetab, hvorfor det for ham drejer sig om at genudlåne pengekapitalen hurtigst muligt. Bankerne muliggør - gennem koncentration af pengemarkedet - at ledig kapital kan tilbagebetales med kort varsel 
og genudlånes. Indskyderne anbringer deres penge i banken for at sikre sig en fast rente af deres penge. Banken koncentrerer på sin side den tilgængelige lånekapital og udnytter mulighederne for at udlåne disse penge. De fungerende kapitalister kan henvende sig til banken med deres kortfristede eller langfristede låneansøgninger og opnå bankkredit, som gør det muligt for den lånende kapitalist at disponere over en større mængde giropenge (som til en hver tid kan omdannes til kontanter) end han faktisk har indskudt i banken (overtrak). Udsvingene i størrelsen af den udlånte pengemængde svarende til valoriseringsprocessens betingelser (se $\S 43$ ) reducerer den fungerende kapitals størrelse og forøger således den årlige nettovaloriseringsrate. Denne mulighed for at undgå ledige penge - og på denne måde øge profitraten - gør imidlertid den individuelle fungerende kapitalist mere følsom overfor forstyrrelser på pengemarkedet. Især mærkes andre kapitalers valoriseringsproblemer tydeligere.

Bankerne spiller hovedrollen i skabelsen af kreditsystemet, som letter anbringelsen af den samlede samfundsmæssige pengekapital. Udviklingen af kreditrelationer øger samtidig de fungerende kapitalers afhængighed af bankerne.

I det omfang Marx behandlede kredit og kreditsystemet i Kapitalen er det indeholdt i tredie bind, 5. afsnit. Engels skriver i forordet til tredie bind, at afsnit 5 har frembudt den »største vanskelighed «: »Her foreligger der med andre ord ikke et færdigt udkast, ikke engang en disposition, hvis omrids kunne udfyldes, men kun et tilløb til udarbejdelse, der i mere end ét tilfælde ender i en ikke-ordnet mængde af optegnelser, bemærkninger og materialer i ekscerptform «. (Rh. 3, 11; K3, 12)

Det første kapitel, som omhandler kredit, »Kredit og fiktiv kapital« (kap. 25), starter med ordene: »En indgående analyse af kreditvæsenet og af de hjælpemidler, det skaber (kreditpenge osv.) ligger uden for vor plan«. (Rh. 3, 518; K3, 413)

Marx diskuterer først vekslen, som »basis for de egentlige kreditpenge « og foretager derpå, efter nogle ekscerpter, en »logisk-historisk « udvikling fra pengehandelskapital til banken:

»I tilslutning til denne pengehandel udvikles den anden side af kreditvæsenet, forvaltningen af den rentebærende kapital eller pengekapitalen som en særskilt funktion for pengehandlerne. Lån og udlån af penge bliver deres særlige forretning. De optræder som formidlere mellem de virkelige udlånere og lånere af pengekapital. Generelt udtrykt består bankforretning i denne henseende $\mathrm{i}$ at koncentrere udlånskapitalen i sin hånd til store masser, således at det ikke er den enkelte pengeudlåner, men bankierne, der som 
repræsentant for alle pengeudlånere står overfor de industrielle og kommercielle kapitalister.« (Rh. 3, 521ff; K3, 416).

Herpå følger en diskussion af bankindskuddenes forskellige kilder og derpå en række ekscerpter med korte indskudte kommentarer fra Marx, tillige med et tre sider langt indskud fra Engels. Det følgende kapitel »Akkumulation af pengekapital, dens indflydelse på rentefoden « (Kap. 26) består også hovedsageligt af ekscerpter, især fra parlamentsrapporter. Kapitel 27, som Engels har givet titlen »Kredittens rolle i den kapitalistiske produktion «, behandler for størstedelen aktieselskabet som »ophævelse af kapitalen som privatejendom inden for grænserne af den kapitalistiske produktionsmåde selv.« (Rh. 3, 568; K3, 452; se Eldred 1984, § 37 Aa).

Kapitel 28 hører efter sit indhold til Teorier om Mervardien. Kapitel 29, »Bankkapitalens bestanddele«, introducerer begreberne kapitalisering samt diskontering af veksler, og forskellige aspekter af bankens transaktioner med veksler, indskud og giro diskuteres. De tre kapitler 30, 31 og 32 med den fælles titel »Pengekapital og virkelig kapital « er fra Marx’ side et fors $\varnothing g$ på - igen blandet op med ekscerpter - at behandle økonomiens konjunkturcyklus i sammenhæng med kreditsystemets mekanismer (især i relation til størrelsen af udlåns-pengekapitalen). Kapitel $33 »$ Omløbsmidlet under kreditsystemet « består hovedsageligt af ekscerpter fra parlamentsrapporter.

Vi har fulgt Marx hvad angår udviklingen af banken fra begrebet om pengehandelskapital. Ligeledes unders øger vi de generelle forhold og aktiviteter omkring bankhandel (veksler, pengesedler, checks, diskontering, lån og udlån, girotransaktioner). I modsætning til Marx’ er vores behandling mere passende anbragt i cirkulationsanalysen, hvilket er muligt for os, da renteformen allerede blev udviklet efter produktionsanalysen ( $\$ 24 \mathrm{ff})$. Marx’ fors $\varnothing \mathrm{g}$ på at udarbejde en cyklusteori må efter vores opfattelse udarbejdes på et senere trin af den systematisk fremstilling, nemlig i konkurrenceanalysen, hvor overakkumulationen af kapital bliver behandlet. Hovedproblemet er at udsondre den almene begrebslige argumentation - for så vidt denne eksisterer - fra det empiriske materiale om kriserne i England mellem 1848 og 1857.

\section{$\S 54$}

Størrelsen af den fungerende kapital kan også reduceres, ligesom cirkulationstiden kan forkortes, såfremt den industrielle kapitalist eller købmandskapitalisten i stedet for at sælge varer mod kontanter eller kontantsymboler (giro-penge), sælger på (kommerciel) kredit med en veksel, som er et løfte om betaling på et senere tidspunkt, på forfaldsdagen. Den sælgende kapitalist realiserer da sine varer mod en veksel, som repræsenterer penge i fremtiden. 
Ved at modtage varer på kredit, sparer den købende kapitalist sig selv for besværet med at låne pengekapital, eller han undgår at vente på, at den udlagte kapital vender tilbage, således at købet muliggøres. Men som en »nogetfor-noget « -forretning må han betale den sælgende kapitalist en rente i form af en højere pris, som udregnes i forhold til vekslens løbetid. Varepriserne kan således kategoriseres som kontantpriser og kreditpriser. Den veksel, som den sælgende kapitalist modtager, kan anvendes som cirkulationsmiddel for at tilvejebringe yderligere varer, så længe den sælgende kapitalist er villig til at give kredit. Afhængig af det omfang i hvilket vekslerne kan cirkulere, kan et større antal transaktioner blive effektueret. Såfremt kapitalisterne generelt tillader udstedelse af veksler, vil der på forfaldsdagen kun være en mindre saldo at udrede i giro- eller guldpenge.

\section{$\S 55$}

Omfanget af veksel-cirkulation kan øges gennem bankernes engagement $\mathrm{i}$ de kommercielle kreditrelationer. Banken accepterer vekslen og giver sin egen veksel, en banknote (pengeseddel), i stedet. Denne kan dog indløses som kontanter på given foranledning, ikke blot på en specificeret fremtidig dato. Banknoten behøver ikke have form af papirpenge udstedt af banken, men kan simpelthen være en kreditgaranti i form af overtrak gennem etableringen af en bankkonto. Den kapitalist, som konverterer vekslen i en bank, kan da købe de varer han $\emptyset$ nsker med bankens kreditgaranti, som er mere umiddelbart acceptabel som betalingsmiddel, så længe der ikke hersker tvivl om bankens solvens. Ved at købe vekslen bliver banken den oprindelige udsteders kreditor og kan kræve vekslen indfriet på forfaldsdagen. Såfremt diskonteringspraksis er udbredt, er det bankerne, der gensidigt anmoder om betaling for de købte veksler hos hinanden som repræsentanter for respektive vekseludstedende kapitalister. Det sæt af transaktioner, som veksler og diskontering gennemløber, sker ved hjælp af en relativ lille mængde guldpenge. Indenfor banksystemet må en clearing finde sted så længe bankerne opfylder deres kunders kreditefterspørgsel. Clearingen af diskonterede veksler indenfor banksystemet svarer til clearingen af checks. Begge aktiviteter reducerer den mængde guldpenge, som er nødvendig til at få varetransaktionerne i $\varnothing$ konomien til at glide. Guldpenge anvendes til udligninger mellem bankerne, mens bankens indskydere normalt har mulighed for at ordne betalinger med giropenge.

\section{$\S 56$}

I og med bankerne garanterer kredit ved at tillade indskyderne at overtrække deres giropengekonti (som er den almindelige form for kreditskabelse $\mathrm{i}$ 
dag), fungerer bankerne også som skabere af giropenge. Det er nemlig ikke mængden af guldpenge, som indskydes i banker, der udgør overgrænsen for hvad banken kan udlåne til kapitalisterne. Selvom giropenge på given foranledning kan konverteres til kontanter (på dette trin kun guldpenge), udgør indskydernes kontantkrav i praksis kun en procentdel af de totale reserver, og den totale mængde transaktioner, som effektueres med giropenge (som for størstedelen er kredit garanteret af banken) overstiger langt mængden af kontanter, som er nødvendig for clearingen af checks og veksler mellem bankerne. Som den vigtigste faktor i skabelsen af kreditsystemet smidigg $\varnothing \mathrm{r}$ bankerne kapitalens sammenslyngede kredsløb, men overfører samtidig forstyrrelsen i reproduktionen af individuelle kapitaler, eftersom en banks afvisning af at yde yderligere kredit til én af dets kapitalistkunder normalt også forårsager problemer for andre kapitalister, som har ydet kredit til den kapitalist, der har fået afslag på yderligere bankkredit.

\section{Kapitalens reproduktionsproces}

\section{$\S 57$}

Undersøgelsen af den samlede samfundsmæssige kapitals reproduktion tager sit udgangspunkt i den erfaring, at den samlede vareproduktions materielle skikkelse i en given periode, f.eks. et år, har en vis betydning for reproduktionen af kapital og individer.

Samfundets produktionsproces, som den er repræsenteret ved processens produkt, totaliteten af varer, skulle således ideelt set passe sammen med samfundets forbrugsproces, betragtet i dens totalitet som det samlede forbrug i produktionsprocesser, cirkulationsprocesser og individuelt ved arbejderes, kapitalisters (penge - såvel som aktive kapitalisters) og jordejeres forbrug.

Forholdet mellem den samlede produktionsproces og den samledes forbrugsproces formidles af kapitalens valoriseringsbevægelse. Produktionens og forbrugets materielle indhold formidles af kapitalens valoriseringsform i bred betydning, heri indbefattet arbejderes, pengekapitalisters (bankers og indskyderes) og jordejeres deltagelse i valoriseringsprocessen. Dette forhold mellem indhold og form er endnu ikke blevet undersøgt i den systematiske fremstilling. Indtil nu har det været antaget, at vareproduktionsmidler eller cirkulationsmidler, som den enkelte kapital har behov for, findes på markedet. Reproduktionsprocessen betragtes her som reproduktion af kapital og ikke af arbejdere eller andre figurer. Som før antager vi, at der på markedet findes de arbejdere, som kapitalen har brug for, og at kapitalen også råder over passende jordarealer. Restriktio- 
ner, som mangel på arbejdere og jord påfører reproduktionsprocessen, vil først blive undersøgt i konkurrenceanalysen (jfr. Eldred 1984, del IIIc; $\S \S 57 f ;$; $\S 65 f f)$. For den samlede samfundsmæssige kapital er der et dobbelt reproduktionsproblem: for det første problemet med at sælge de producerede varer til andre kapitaler eller individer, som forbruger varerne, til priser, som muliggør, at der skabes en virksomhedsprofit, og for det andet problemet at købe passende industrielle varer, så virksomheden kan fortsætte sin aktivitet som kapital. Problemets to aspekter er hinandens modsatte: Den ene kapitalists eller individs køb af varer er på samme tid salg af varekapital for en anden kapital. Grænsefladen mellem den fuldførte produktionsproces og (den individuelle eller produktive) forbrugsproces er markedet: mødestedet for købere og sælgere. Den producerede vare kan kun formidlet gennem penge gå over i en forbrugsproces. Disse penge optræder så i en kapitals eller nogle kapitalers valoriseringsbevægelse. På dette trin i fremstillingen, hvor kreditsystemet er blevet tematiseret ( $\$ 53)$, sker pengeformidlingen gennem forskellige kreditrelationer og typer af kreditpenge, som opstår i forbindelse med bankernes aktivitet. Det kan hurtigt indses, at den samlede samfundsmæssige reproduktionsproces er så kompliceret, at en simpel afgrænset analyse er umulig.

Marx introducerer problemet med reproduktionen af den samlede samfundsmæssige kapital på en lignende måde:

»Vi kan nu ikke længere nøjes med at forudsatte - som da vi analyserede den enkelte kapitals produktværdi - at den enkelte kapitalist først kan omsætte sin kapitals bestanddele i penge ved at sælge sit vareprodukt, og at han bagefter atter kan forvandle pengene til produktiv kapital ved at købe produktionselementerne på varemarkedet.« (Rh. 2, 506; K2, 392)

Med henblik på undersøgelsen af reproduktionen indfører Marx et antal yderst restriktive antagelser i fremstillingen, inklusive følgende:

i) Alle varer sælges til deres »værdier« som defineret ved arbejdsværditeorien.

ii) Alle kapitalers omslagstid er 1 år, idet der heri er indbefattet en produktionsperiode på 1 år og en cirkulationstid, som er 0 , og at alle processer foregår synkront.

iii) Cirkulationsomkostningerne er 0

iv) Der anvendes kun en type penge, guldpenge. Der er følgelig ingen kreditrelationer.

Med disse antagelser $\emptyset$ nsker Marx at artikulere, hvordan kapitalens vardireproduktion i en samfundsmæssig skala - udtrykt ved værdiformskategorierne gammel værdi (konstant kapital) og ny værdi (variabel kapital plus merværdi) - konfronteres med brugsværdi-opdelingen på to produktionsafdelinger. Arbejderklassen optræder her som en nødvendig formidler af reproduktionen af den samlede sam- 
fundsmæssige variable kapital, idet klassen bruger den modtagne løn (og på denne måde orienterer sig mod sine behov for forbrug). Marx opdeler den samlede samfundsmæssige vareproduktion på to afdelinger: produktion af produktionsmidler (I) og produktion af individuelle forbrugsgoder (II), og han betragter derefter det samlede samfundsmæssige vareprodukt under hensyn til de tre kategorier: konstant kapital, variabel kapital og merværdi. Hans argument kan læses uden arbejdsværditeoriens antagelse om, at priser svarer til arbejdsindhold. Antagelserne ii), iii) og iv) ligesom opdelingen af den samfundsmæssige produktion på kun to afdelinger (jfr. § 58) simplificerer i ekstrem grad fremstilling af den samlede samfundsmæssige kapitals reproduktion. I modsætning hertil unders $\emptyset$ ger denne fremstilling kapitalreproduktionen uden disse antagelser med henblik på at vise, hvordan de utallige formidlinger er viklet ind i hinanden i den samlede reproduktionsproces. Med hensyn til antagelse iv) vil vi mere detaljeret i $\S 59$ undersøge pengeformidlingen af den samlede proces.

Da vi ikke anlægger restriktive antagelser, er det ikke muligt at komme med simple taleksempler, som Marx gør. Vi må i stedet for stille os tilfredse med en kvalitativ forståelse af den materielle cirkulation og produktion af varer og den monetære formidling heraf. Når man opgiver den aprioristiske ricardianske arbejdsværditeori, opgiver man også muligheden for at etablere kvantitative love om kapitalens reproduktion udtrykt som erstatning af arbejdsindhold, som i enhver henseende er en ubegrundet ptolemæisk konstruktion. Ikke alene ortodoks marxistisk økonomisk teori, men også borgerlig $\emptyset$ konomisk teori fors $\varnothing$ ger at etablere præmonetære »bevægelseslove « for den samlede $\varnothing$ konomiske proces. Disse fors $\varnothing \mathrm{g}$ på modelbygning er baseret på den fejlagtige opfattelse, at værdiformsrelationer kan bestemmes kausalt på grundlag af et eller andet apriorisk, formuafhængigt princip eller i det mindste kan antages på anden måde at kunne beskrives kvantitativt, f.eks. ved matematiske funktioner, som er konstrueret på grundlag af empiriske data. Den værdiformsanalytiske kritik af aprioristiske teorier ${ }^{2}$ er $\emptyset$ delæggende for ethvert fors $\varnothing g$ på at opstille en forklaring på den kapitalistiske økonomis fænomenale bevægelse ved hjælp af et underliggende, kvantitativt bestemt, præværdiforms væsen.

\section{$\S 58$}

Det samlede samfundsmæssige vareprodukt falder i fire kategorier: varer som har en materiel form, der muliggør, at de kan forbruges af:

industrielle kapitaler (produktionsmidler)

købmandskapitaler som anvendes til varecirkulation

bankkapitaler (midler anvendt ved bankvirksomhed),

2. Leif Hansen, Knud Pedersen, Thomas Stenderup, On methodological problems in economic theory. A critique of aprioristic value theory. Institut for Socialvidenskab, Roskilde universitetscenter, skriftserie nr. 15, 1984. 
og individuelle arbejdere, kapitalister og jordejere (individuelle forbrugsartikler).

Denne kategorisering er udtømmende (på dette trin i fremstillingen), men den udelukker ikke, at mange varer måtte blive konsumeret $\mathrm{i}$ alternative sfærer. Svarende til de fire sfærer er der fire aggregerede afdelinger for vareproduktion, som for nemheds skyld antages ikke at overlappe hinanden, dvs. at hvert vareprodukt kan indpasses utvetydigt i netop én forbrugssfære. De fire afdelinger er:

I: Produktion af produktionsmidler.

II: Produktion af varecirkulationsmidler

III: Produktion af midler, som anvendes ved bankvirksomhed.

IV: Produktion af individuelle forbrugsartikler.

Man kan se, at begrebet brugsværdi, som første gang blev introduceret i analysen af produktionen $(\S 18)$, igen indtager en central rolle. Fordi cirkulationsstadierne ikke falder fuldstændig bort for den industrielle kapital, anvendes nogle af varerne, som en industriel kapital køber, strengt taget uproduktivt som cirkulationsmidler. Denne detalje vil imidlertid ikke blive betragtet her.

I stedet for Marx' opdeling af vareproduktionen på to grundliggende afdelinger, har vi en opdeling på fire afdelinger. De to ekstra afdelinger fremkommer, fordi cirkulationsomkostningerne og cirkulationsaktiviteterne ikke ignoreres, og også fordi disses autonome skikkelse som købmands- og bankkapital tages i betragtning. De eneste cirkulationsomkostninger, som Marx behandler i sine reproduktionsskemaer, er samfundets omkostninger ved at opretholde udbudet af guldpenge. Da cirkulationsomkostninger og -tid er vigtige temaer i cirkulationsanalysen, finder vi, at det er en begrænsning i Marx' fremstilling, at der abstraheres fra cirkulationsomkostninger og -aktiviteter.

\section{$\S 59$}

Samfundets totalarbejder falder i seks kategorier svarende til de fire produktionsafdelinger plus sfærerne for handels- og bankaktiviteter. Tilsvarende udlejer jordejerne deres jord til de seks kategorier af fungerende kapital. Det totale vareprodukt distribueres til de forskellige fungerende kapitaler og til individerne vha. købmandskapitalens aktiviteter. Afdeling I's produktion omfordeles mellem de industrielle kapitaler; afdeling II's produktion fordeles til købmandskapitalerne; afdeling III's produktion til bankerne og endelig fordeles afdeling IV's produktion til individuelle arbejdere, kapitalister og jordejere. Fordelingen af produktionens materielle elementer og af vareproduktet komplementeres af penges bevægelse som kapital og som individuelle betalingsmidler for subsistensmidler. Penge indsat i ban- 
ker, uanset hvorfra de kommer, genudlånes som kapital til de fungerende kapitalister. Renten på disse lån strømmer til bankerne, og derefter delvist til indskyderne. Lånekapital og salgsindtægter bruges af de fungerende kapitalister til at købe industrielle varer og til at betale lønninger, rente og jordrente. Indkomsterne, som arbejdere, jordejere og kapitalister modtager, bruges for en del til subsistensmidler, mens resten placeres i bankerne, hvor der tjenes en rente. Ligesom i de marxske reproduktionsskemaer, må penge nødvendigvis på forhånd være til rådighed for at det samlede vareprodukt kan cirkulere. Vi betragter eksemplet med den kommercielle kapital. Med lånt pengekapital køber den varer fra industrielle kapitaler f.eks. afdeling IV. Arbejdere, jordejere og kapitalister køber disse varer enten på bankkredit (§ 53) eller ved at hæve indlån, som har været sat til side fra sidste periodes indtægter. (Det forhold at revenu betales bagud, gør det fordelagtigt for revenu-modtagere at opspare en vis del af sidste periodes revenu-indtægt indtil næste udbetaling af revenu). Den kommercielle kapital får således penge tilbage til at dække udlægget til varelager plus omkostningerne til cirkulationsarbejdere, jordrente og rente, og en rest til virksomhedsprofit (hvis ellers alt er gået glat). Cirkulationsarbejdere, ejere af jord, som benyttes af handelskapitalen, og banken betales revenu, som erstatter det, som blev anvendt til privat forbrug i den betragtede periode. Tilsvarende kan de penge, som den kommercielle kapital udlagde til afdeling IV, anvendes af afdeling IV-kapitaler til revenubetalinger (idet der forhåbentligt bliver en rest tilovers som profit til virksomheden). Disse udbetalte revenuer fylder atter op i de respektive private forbrugsfonde eller afbetaler på gæld til banken. Med hensyn til de renter, som den kommercielle kapital betaler til banken realiserer banken en del af virksomhedsprofitten og kan dække nogle omkostninger inklusive betalinger af rente til indlånere. Delingen af den samlede samfundsmæssige merværdi mellem jordejere, banker, kommercielle- og industrielle kapitaler sker delvist ved direkte betalinger (af jordrente og rente) og delvist ved at der skummes noget af varernes salgspriser, når penge skifter ejermænd, fordi enhver kapitalist opererer med visse »margins « mellem købs- og salgspriser.

På dette trin i fremstillingen har vi følgende typer penge: Guldpenge, giropenge/ checks ( $\$ 52$ ), banknoter/overtræk ( $\$ 55)$ og veksler ( 54 ). Veksler og banknoter er kreditpenge baseret på giropenge. Giropenge måles i guldpenge. På dette trin er alle pengebenævnelser guldbenævnelser, alle pengetyper kan konverteres til guldpenge. Så længe guld tjener som absolut pengemateriale, nyder de guldproducerende kapitaler en særlig rolle i den samlede reproduktionsproces. De producerer en (præmonetær) vare, som umiddelbart kan antage pengeform og således ekskludere sig selv fra vareverdenen, (som er prisbestemt). (§ 7). 
Mængden af kreditpenge (veksler), som den fungerende kapital kan udstede, afhænger af dens kreditværdighed, dvs. af hvorvidt man kan få giropenge for dem på forfaldsdagen. Mængden af giropenge (overtræk), som bankerne kan skabe udover den mængde guldpenge, som er indlånt i bankerne, begrænses af deres evne til at omveksle giropenge til guld, når det forlanges. Dette har især betydning ved udligningen af bankernes indbyrdes kasseregnskab, som må ske i guldpenge. Mængden af guldpenge, som indlånes i bankerne, tjener således som et anker for alle andre pengetyper ved at sætte en grænse for, hvor mange kreditpenge (veksler, som normalt diskonteres af banker, og giropenge), der kan skabes i kreditsystemet. De guldproducerende kapitaler har således en betydelig indflydelse på kreditsystemet, idet de bestemmer mængden af guld, som hver periode tilføres systemet. En vis mængde af guldproduktionen indgår som produktionsmidler i produktion af andre varer og er således ikke til rådighed for banksystemet. En anden del af guldproduktionen skal bruges til at erstatte den mængde guldmetal, som ved brug er slidt ned. Resten indgår i banksystemet som ekstra indskud. Den samlede mængde af alle typer penge, som er til rådighed for den samlede reproduktionsproces, er indenfor visse fleksible grænser begrænset af mængden af guldpenge i pengesystemet. Salget af producerede varer skal formidles af penge (af den ene eller anden slags), som er i hænderne på kapitaler eller personer. Personer modtager penge enten som revenu (løn, rente, jordrente) eller som virksomhedsprofit. Den samlede fungerende kapital, som banksystemet stiller til rådighed for de fungerende kapitaler, afhænger af størrelsen af indskud i bankerne. Hvis guldpriserne på varer og de forskellige revenuer skal fastholdes, skal der være en tilstrækkelig pengemængde til rådighed. Specielt i tilfældet med udvidet reproduktion ( $\$ 63$ ), er forøgelsen af antallet af transaktioner begrænset af, i hvor høj grad penge er til rådighed og i sidste instans af udbudet af guldpenge. I et vist omfang kan en stigning i pengenes cirkulationshastighed kompensere for mængden af penge, således at samme pengemængde udfører flere transaktioner end før. Den måde, som bankerne organiserer behandlingen af penge, sætter imidlertid tekniske grænser for mulighederne for at $\emptyset$ ge cirkulationshastigheden. Et ekspanderende kapitalvaloriseringsomfang gennem udvidet reproduktion kan således blive forpurret af mangel på guldpenge, der er til rådighed. Selv om den samlede varemasse er blevet materielt forøget, vil den i forhold til tidligere perioder kun kunne sælges for den samme, eller en kun lidt forøget, samlet pris. Varernes enhedspriser ville falde, og de fungerende kapitaler vil på grund af profitklemmen gøre alle mulige anstrengelser for at reducere de nødvendige revenuudbetalingerne. En ekspanderende reproduktionsproces ville kun være mulig, hvis den blev fulgt op af en kontinuerlig opskrivning af penge (deflation), hvilket ville fremtvinge en skærpet klassekamp om indkomsterne, dvs. fungerende kapitaler ville være nødt til at presse revenuerne ned for at kunne fastholde virksomhedsprofitterne. 
Reproduktionsprocessens afhængighed af mængden af guldpenge i banksystemet kan kun undgås ved introduktion af statspapirpenge (lovlige betalingsmidler), som overskærer forbindelsen mellem pengeudbud og udbudet af en speciel (præmonetær) vare. Dette forgriber imidlertid et mere udviklet analysetrin, hvor begrebet statsmagt er udviklet (jvf. Eldred 1984 § 85 og § 91). På dette trin kan det ses, at et vigtigt formål med statens pengepolitik er at forsøge at tilpasse væksten i pengemængden til det, som er nødvendigt i den samlede reproduktionsproces. Men selv da kan tilpasningen af pengeudbudet i banksystemet til de fungerende kapitalers behov kun reguleres aposteriori, efter at den altid svingende pengeefterspørgsel har gjort sig selv mærkbar. Det er ren og skær held, hvis pengemængden nøjagtig korresponderer med den samlede reproduktionsproces' behov. Om noget, skulle staten sigte mod en rolig inflation, som tvinger revenumodtagerne til at kræve mere af de fungerende kapitaler for at følge med. Den modsatte situation med et utilstrækkeligt pengeudbud forårsager deflation, som umiddelbart stiller den fungerende kapital overfor valoriseringsproblemer.

\section{§ 60}

Reproduktionen af hver enkelt kapital skal foregå inden for rammerne af den samlede bevægelse af varer, andre produktions- og cirkulationselementer, og af penge, hvis reproduktionen da ellers overhovedet skal ske. For den enkelte kapital betyder reproduktionen, at omkostningerne, som fremkom i forbindelse med kapitalens aktivitet, bliver dækket af indtægter fra salg af varer.

Herudover skulle der blive en profit tilovers til virksomheden. Salget af de producerede industrielle varer afhænger i sidste ende af deres brugbarhed, og om forbrugeren (enten det er et individ eller en kapitalist) er i stand til at betale for varen. I særdeleshed realiserer det enkelte individs indkomst værdien af produkter fra afdeling IV. Vareprodukter, som ikke finder hensigtsmæssig anerkendelse i pengeform vil ikke blive reproduceret af den enkelte industrielle kapital, som det drejer sig om. Den enkelte industrielle kapital må indrette sig efter dets produkters succes eller fiasko med hensyn til at antage pengeform. Handelskapitaler spiller en formidlende rolle mellem de industrielle kapitaler og de endelige forbrugere. De reagerer på, at varebeholdningen er usælgelig eller sælges til utilstrækkelige priser, ved ikke påny at købe fra de industrielle kapitaler. Banker, som handler med varen 'lånekapital', oplever ikke vanskeligheder på grund af varens materielle form som brugsværdi. Penge, som indlånes i bankerne, kan genudlånes, og bankerne skaber selv giro-penge på grundlag af indlån. Hvis disponibel pengekapital (enten kontanter eller giropenge skabt af 
banken) ikke efterspørges af andre fungerende kapitaler, så tjener bankerne ikke rente på potentiel lånekapital. De svarer med at nedsætte renten, både på udlån og på indlån. Dette indskrænker deres mulige virksomhedsfrofit, men forårsager ikke valoriseringsvanskeligheder i sig selv. Bankernes valoriseringsvanskeligheder opstår for det meste ikke på grund af varens materielle form, men snarere som en konsekvens af valoriseringsvanskeligheder for andre kapitaler, som ikke kan opfylde deres kreditforpligtelser. En banks eksistens er direkte truet, hvis de pengehandelsaktiviteter, den udfører, ikke længere er nødvendige for den samlede, samfundsmæssige, fungerende kapital. De omkostninger, som banken pådrager sig ved pengehandelsaktiviteterne, kompenseres i så fald ikke af den effektive efterspørgsel efter dens bankydelser.

Problemet med reproduktion af en individuel kapital drejer sig på ingen måde om at reproducere »værdier « forstået som arbejdsindhold. Der er nærmere tale om problemet med at reproducere investerede pengesummer i et omfang, så de også kan dække en residual virksomhedsprofit. Værdirelationerne er allerede udtrykt i prisrelationer, som bestemmer det omfang, i hvilket det udførte vareproducerende arbejde anerkendes som del af vareværdi-totaliteten og dermed bestemmer hvorvidt de påførte omkostninger kompenseres gennem værdidannelse. Vareverdenens værdi-almenhed, som blev tematiseret allerede i $\S 1 \mathrm{ff}$, komplementeres på dette niveau af en brugsværdistruktur svarende til de særegne produktionsprocessers og konsumtionsprocessers gensidige afhængighed. Produktionskategorierne, som blev indført i § 58, er en grov differentiering af det totale vareprodukt og dets produktionsprocesser svarende til brugsværdien, dvs. svarende til vareproduktets endegyldige bestemmelsessted i en specifik type konsumtionsproces. Denne kategorisering kunne godt forfines, f.eks. svarende til sondringen mellem fix og cirkulerende kapital. Den kvalitative pointe er imidlertid allerede klar: hvis den indre forbindelse mellem produktion og cirkulation overhovedet etableres, så sker det via en repræsentation af produkterne som vareværdier. Vareverdenens værditotalitet har en relation til produkternes brugsværdi-totalitet, som er bestemt af varernes endegyldige konsumtion. Brugsværdi-totaliteten er en konkret totalitet i modsætning til værditotalitetens abstrakte almenhed. Varens særegenhed (§ 4) spiller således en væsentlig rolle i sammenhæng med den totale samfundsmæssige kapitals reproduktion. Denne særegenhed må ikke desto mindre underlægges pengenes abstrakte almenhed i hvilken al særegenhed udslettes. Produktionsprocessens særegenhed og den endelige konsumtionsproces' særegenhed kan kun formidles gennem værdiudtrykkets abstrakte almenhed i penge. Eftersom produktets værdiform, dets væren-som-vare, først antages post facto, efter dets produktion, så kan tilpasningen af produktionen til konsumtionsprocessens kon- 
krete totalitet på samme måde først foregå post facto med en større eller mindre grad af forvridning af den produktive aktivitet. Da denne post facto tilpasning kun formidles gennem værdiformen, kan den ikke garantere en tilpasning i den rigtige retning. Den individuelle kapitals svar på valoriseringsvanskeligheder, hvor den orienterer sig mod aktuelle muligheder for at forbedre valoriseringen, kan nemt i den næste periode blot forvarre valoriseringsproblemerne. Ethvert misforhold mellem produktion og cirkulation viser sig kun kvantitativt, i prisformen. De kvantitative udsving i priserne, en abstrakt bevægelse i prisformen, kan ikke løse koordineringsproblemerne i en kapitalistisk økonomi. Uanset denne proces med vedvarende misforhold, så forbliver værdiformen, som den kvalitative, abstrakte form for anerkendelse af det samfundsmæssige arbejde, uberørt af kvantitative udsving. Kun en alternativ form for samfundsmæssig konstituering af arbejdet ville tendentielt sætte spørgsmålstegn ved værdiformen.

\section{§ 61}

Man kan skrive en serie simple ligninger, der opløser de samlede priser for varerne, produceret $\mathrm{i}$ hver afdeling $\mathrm{i}$ en given periode, i omkostninger plus virksomhedsprofit. Eftersom varehandelskapitalens aktiviteter formidler salget af industrielle varer, er der tale om to serier af simple ligninger, hvor hver sereie indeholder fire ligninger - en for hver afdeling. Der ud over er salgspriserne for fødevarerne lig med de samlede indkomster ( $1 \emptyset \mathrm{n}$, jordrente, virksomhedsprofit, rente), der er brugt til dem, og bankernes samlede renteindtægter kan opløses i omkostninger plus bankernes virksomhedsprofit. Dette giver ialt ti ligninger. Betragtet som ligninger, der udtrykker værdirelationer mellem dele af det totale produktions-, handels- og konsumtionssystem, udtrykker ligningerne betingelser for reproduktion af dele af den totale samfundsmæssige kapital. Alle virksomhedsprofitstørrelser må være positive for at reproduktionen skal lykkes. Negativ virksomhedsprofit påtvinger en omstruktureringsproces for den afdeling, der er tale om (f.eks. øget effektivitet, forøget omslagshastighed, ophør af visse kapitalers aktiviteter). Fordi værdirelationerne kun resulterer post facto, efter at varerne er blevet produceret og er kommet på markedet, så kan omstruktureringen af produktionen og handelsaktiviteterne kun reagere på de faktiske værdirelationer mellem afdelingerne. Der ud over er pengene og kreditten, som banksystemet skal stille til rådighed for den samlede proces, i en konstant tilpasningsproces. Den materielle reproduktionsproces og selve systemet med pengemæssig formidling kan geråde ud i en disproportionalitet ( $\$ 59$ ), som kun kan justeres bagudrettet (og da måske i forkert retning). Kreditklemme og inflation er fænomener, 
som er resultat af et misforhold mellem den materielle og pengemæssige side af reproduktionen.

a) De ti ligninger, som blev omtalt ovenfor, er ikke udtømmende. De udtrykker nogle af de værdirelationer, der eksisterer mellem $\varnothing$ konomiens afdelinger og det individuelle forbrug. Varernes brugsværdi kommer i forgrunden på dette niveau af analysen, sk $\varnothing$ nt brugsværdierne stadig kun er inddelt i fire grove kategorier svarende til arten af deres endegyldige konsumtion. Værdirelationerne (i den udvidede betydning, der includerer lønnen, jordrenten, virksomhedsprofitten og renten som værdiformer) frembringes a posteriori i vareproduktets materielle distribution til de forskellige sektorer i $\varnothing$ konomien og til den individuelle forbrugssfære. Materielle disproportionaliteter mellem det totale vareprodukt og de materielle forbrugsbehov i den produktive, uproduktive og individuelle konsumtion afspejles kvantitativt i værdirelationerne i de priser, der betales for varerne. Priserne er på deres side bestemmende for om - og i hvilken udstrækning - de omkostninger, som de industrielle kapitaler i de forskellige afdelinger har pådraget sig, bliver dækket. Konkurrenceanalysen vil i behandlingen af tendensen til dannelsen af en gennemsnitlig, årlig nettoprofitrate (jvf. Eldred, 1984, §§ 30ff) eksplicit tematisere, hvorledes kapitalerne reagerer på de opnåede priser.

b) Marx refererer til vigtigheden af de industrielle varers brugsværdi, dvs. arten af deres endegyldige forbrug, hvor han introducerer spørgsmålet om kapitalens reproduktion:

»Sålænge vi betragtede værdiproduktionen og kapitalens produktværdi individuelt, var vareproduktets naturalform ganske underordnet for analysen.... For så vidt der var tale om kapitalens reproduktion, var det tilstrækkeligt at forudsætte, at den del af vareproduktet, som repræsenterer kapitalværdien, inden for cirkulationssfæren ville finde lejlighed til igen at forvandle sig til sine produktionselementer og dermed atter tage form af produktiv kapital. Det var også tilstrækkeligt at forudsætte, at arbejder og kapitalist på markedet ville forefinde de varer, som de giver arbejdsløn og merværdi ud til. Denne rent formelle fremstillingsmåde er ikke længere tilstrækkelig, når vi betragter samfundets totalkapital og dens produktværdi.« (Rh. 2, 507-08; K2, 393)

c) Den proces, gennem hvilken der søges skabt en passende relation mellem produktion og konsumtion, er en række af kontinuerte misforhold, som tvangsmæssigt bringes for dagens lys af værdirelationer, der tvinger de producerende kapitaler til at ændre produktionsprocessen eller måske til helt at indstille produktionen. Denne proces, hvor der søges proportionalitet gennem kontinuert disproportionalitet, skaber forstyrrelser af større eller mindre grad. »Selve processens komplicerede karakter giver lige så mange anledninger til unormalt forløb.« 
(Rh. 2.2, 631; K2, 491). Denne unormalitet ved den materielle produktions totale proces i dens kapitalistiske form er et stedsevarende problem. Forsøget på at opnå proportionalitet gennem disproportionaliteter kan enten, ved et tilfælde, føre til en større grad af proportionalitet mellem produktion og konsumtion eller til en endnu større disproportionalitet (jvf. § 60). Dette beskrives i økonomisk teori som en (skadelig) spindelvaevseffekt.

\section{$\S 62$}

Den del af det totale samfundsmæssige vareprodukt, som købes som fix-kapital (produktions- eller cirkulationskapital) sættes i bevægelse $\mathrm{i}$ arbejdsprocesser, hvor den fungerer $\mathrm{i}$ et antal af den cirkulerende kapitals omslag, som sædvanligvis løber op i et antal år. Omkostningerne til fix-kapital slår således kun om i løbet af en lang periode, i hvilken fix-kapitalen i dens materielle form konsumeres gradvis. Den andel af det totale vareprodukt, der finder anvendelse som fix-kapital, udgør således et relativt stort fradrag fra varerigdommen, der kun vil bære frugt (i form af nye varer) over en lang periode. Det totale vareprodukt må have nået en tilstrækkelig størrelse for at kunne tåle et fradrag, som ikke umiddelbart bidrager til den samlede samfundsmæssige individuelle konsumtion (i modsat fald må den samlede samfundsmæssige, individuelle konsumtion - og det vil først og fremmest sige arbejderklassens - begrænses drastisk). Den pengekapital, der er nødvendig til investeringer i fixkapital, må stilles til rådighed af banksystemet. Den del af det totale samfundsmæssige vareprodukt, der består af varer, der kan konsumeres som fixkapital, må finde vej ind i arbejdsprocesser, hvor fix-kapital skal erstattes in natura efter en levetid på adskillige omslag af den cirkulerende kapital. I andre arbejdsprocesser (kommercielle og produktive) behøver fixkapitalen ikke at blive erstattet in natura i den betragtede periode, men $\mathrm{i}$ stedet må der sørges for en afskrivningsfond m.h.p. dens kommende erstatning. Afskrivningsfonden, der består af brakliggende midler, kan stilles til rådighed for banksystemet indtil fonden skal bruges til erstatning af fix-kapitalen. De kapitaler, som erstatter fix-kapital i den betragtede periode, trækker på den samlede samfundsmæssige afskrivningsfond for at købe de nødvendige varer. Eller de køber fix-kapital på varekredit, hvilket muliggør afbetaling over en lang periode. Den kapital, der producerer fix-kapital, må kunne bære en sådan langvarig kredit eller må henvende sig til banksystemet for at diskontere en langfristet veksel. Det grundliggende problem er, at den del af det totale vareprodukt, som er bestemt til brug som fix-kapital, må finde vej til passende arbejdsprocesser, hvor der er behov for ny eller for erstatning af fix-kapital, og omvendt må kapita- 
len, der har brug for erstatning af fix-kapitalen, kunne finde den til rådighed for køb på markedet. I modsætning til flertallet af varer, som anvendes som cirkulerende kapital eller forbruges individuelt, så repræsenterer fix-kapital-varer sædvanligvis en uhyre værdimængde. En enkelt kapital producerer måske kun meget få enheder af en fix-kapital-vare på et år eller ovenikøbet mindre end en enhed. Hvis en eller flere af disse enheder viser sig at være usælgelige eller kun sælgelige til en pris, der er utilstrækkelig til at dække investeringen, fordi den ikke er efterspurgt i nogen arbejdsproces, så er den producerende kapitals valorisering i akut fare. Kapitaler, der producerer fix-kapital-varer, søger at undgå dette problem ved kun at producere mod faste ordrer for på den måde at unddrage sig nogle af markedets lunefuldheder. Størrelsen af det tidsrum, der er involveret, kan imidlertid være så stort, at den kapital, der bestiller fix-kapital-varer til en bestemt dato i fremtiden, meget vel kan befinde sig i en position, hvor den ikke længere har brug for dem eller råd til dem. Eller det kan ske, at den bestilte fix-kapital allerede er overgået teknologisk, når dens produktion er tilendebragt. I så fald er det blot et spørgsmål, hvorvidt den producerende eller ordregivende kapital bærer tabet. Ordresystemet kan ikke ophæve de forst $\varnothing$ rrede disproportionalitetsvanskeligheder mellem produktion af fix-kapital-varer og erstatning af fix-kapital in natura. Disproportionalitetsproblemerne mellem produktion og konsumtion i den samlede reproduktionsproces dukker op i forstørret målestok i det særlige tilfælde med fix-kapital-varer.

I Marx' behandling af erstatningen af den fixe kapital (K2, kap. 20, afsnit 11) lægges der stor vægt på spørgsmålet, hvorledes pengene til erstatning af fixkapitalen kan fremskaffes. Han argumenterer indenfor rammerne af et simpelt skema, hvor den konstante kapital-komponent i afdeling II (for Marx, konsumtionsmidlerne) skal udveksles mod nyværdikomponenten i afdeling I (produktionsmidlerne) (jvf. Rh 2, 573ff; K2 446ff). Som et resultat af hans forsimplende antagelser (jvf. § 57), kommer han til det resultat, at værdien (målt i penge) af den fixe kapital i afdeling II, som skal erstattes i den løbende periode, må være lig med værdien af afskrivningen af fix-kapital i afdeling II, som endnu skal akkumuleres i en afskrivninsfond. Med vores mere komplicerede skema bliver problemet om erstaning af fix-kapital mere kompleks. Banksystemet skal sørge for fondene til erstatning af fix-kapital. Hovedkilden til disse fonde er andre kapitalers fixkapital-afskrivningsfonde, som temporært er stillet til rådighed for banksystemet. Den kendsgerning, at disse gradvis akkumulerede fonde er indsat i banksystemet, som på sin side kan låne dem til enhver afdeling i økonomien, betyder, at balancen mellem nye fix-kapitalinvesteringer og til rådighedstående afskriv- 
ningsfonde ikke behøver at være til stede indenfor hver enkelt afdeling. Der skal blot opnås en balance for $\emptyset$ konomien som helhed. Banksystemets kreditrelationer muligg $\emptyset \mathrm{r}$ blot, at problemet forskydes til det totale samfundsmæssige niveau. Kreditrelationerne muliggør også, at den totale samfundsmæssige afskrivningsfond til erstatning af fix-kapital kan reduceres, eftersom den samme pengekapital kan financiere købet af adskillige fix-kapital fornyelser på forskellige tidspunkter. Den nødvendige pengekapital behøver heller ikke nødvendigvis at være opsparet af de individuelle kapitaler eller af de fungerende kapitaler som helhed, fordi også andre figurer stiller penge til rådighed for banksystemet. Fordi Marx abstraherer fra kreditrelationerne og går ud fra den antagelse, at kapitalisterne arbejder med deres egen pengekapital, så kommer han til det resultat, at de kapitalister, som erstatter deres fix-kapital in natura i en given periode ved at kaste akkumulerede afskrivningsfonde i cirkulation, fremskaffer de penge, som igen kan trækkes ud af cirkulationen af de kapitalister, som stadig sparer op i deres afskrivningsfonde. Under den antagelse, at kapitalisterne opererer med lånekapital, er situationen vendt om: de kapitalister, som lægger noget til side fra salgsprisen på varerne i en afskrivningsfond til senere erstatning af fix-kapitalen, tilvejebringer fondene til banksystemet, som kan lånes til de kapitalister, som ønsker at erstatte den fixe kapital. Fordi Marx abstraherer fra kreditrelationerne, antager afskrivningsfonden skikkelse af pengeophobning i hænderne på kapitalisterne, som ikke lånes til nogen anden kapitalist. Ikke desto mindre leverer hans forsimplede reproduktionsskema nøglen til forståelsen af den fixe kapitals reproduktion. Pengeformidlingen af den fixe kapitals fornyelse er den ene side af problemet. Den anden side er den materielle disproportionalitet, dvs. at de rigtige fix-kapital-arbejdsmidler produceres i de rigtige mængder på de rigtige tidspunkter. Dette sker gennem en flakken rundt i mørket på markedet. Enhver materiel disproportionalitet må tilpasses indenfor rammerne af et kompleks (spindel)væv af a posteriori relationer på markedet. Tilpasningsprocessen kan være af mere eller mindre voldsom natur. På den kapitalistiske $\varnothing$ konomis evigt skiftende sandbanker kan den individuelle kapitalists reaktioner vise sig nøjagtigt at være en forkert reaktion som forværrer disproportionaliteten. De betaler dyrt for deres forkerte 'vurdering' i form af valoriseringsvanskeligheder. Den enkelte kapitalist kan imidlertid ikke holdes ansvarlig for værdiformernes iboende tilfældigheder, - uanset den naive bevidstheds beskyldninger om dårlig ledelse, når tingene øjensynligt går slemt galt.

\section{§ 63}

Den totale samfundsmæssige nyværdi udtrykkes i summen af revenuerne plus virksomhedsprofitten, dvs. i summen af de forskellige klassers indkomster, plus den andel af den totale samfundsmæssige værdi, der er nødvendig for at erstatte de konsumerede cirkulationsmidler. Den 
totale samfundsmæssige gammelværdi er på den anden side den sum, der er nødvendig for at erstatte de konsumerede produktionsmidler (jvf. $\S 44)$. Af den samlede sum af indkomster bruges en del til individuelle konsumtionsartikler og den anden del spares op, dvs. indsættes i bankerne og tjener rente som indlånt pengekapital. Dette tillæg til den totale samfundsmæssige pengekapital kan anvendes af de aktive kapitalister, men kun hvis de materielle forudsætninger for dets anvendelse er til stede. Af interesse hér er kun de industrielle varer, som må være til rådighed på markedet, hvis den totale samfundsmæssige fungerende kapitals aktiviteter skal kunne ekspanderes (dvs. spørgsmålet om ekstra arbejdere og jord lades ude af betragtning hér). Disse ekstra varer må besidde den passende brugsværdiform, hvis de skal kunne anvendes i en udvidet reproduktionsproces. Eftersom beslutningerne om at spare eller forbruge indkomsterne tages individuelt, er det et rent tilfælde, om der er korrespondence eller ej mellem varer bestemt for individuelt forbrug og den forbrugte indkomst. Udbudet af varer til individuelt konsum (produkterne fra afdeling IV) kan enten overstige eller være mindre end den samlede sum penge, der er sat til side til forbrug af individuelle forbrugsvarer. Gennem prisændringer og ændringer i forholdet mellem opsparing og forbrug kan de to mængder bringes tilbage i relation til hinanden. På lignende måde har den totale akkumulerede pengekapital kun en tilfældig relation til det vareprodukt, som kan anvendes til udvidelse af individuelle fungerende kapitalers aktiviteter. Gennem mekanismerne på markedet, inclusive pengemarkedet, ændres mængden af akkumuleret pengekapital, ligesom priserne ændres på de varer, som er til rådighed som produktionsmidler eller som cirkulationsmidler. Kapitalens akkumulation og den resulterende udvidede kapitalreproduktion hviler på basis af dens materielle forudsætningen i det samlede samfundsmæssige vareprodukt. Akkumulation er imidlertid et aspekt af produktionen af relativ merværdi ved anvendelse af større mængder af produktionsmidler (fordi forøgelser i produktiviteten i en arbejdsproces ofte er ledsaget af en stigning i produktionens målestok). Udvidet reproduktion svarer således til kapitalens tendens til at forøge sin samlede valoriseringsbevægelse som en karakteristisk relation mellem indhold og form i den kapitalistiske produktionsmåde.

Pengekapitalen, som står til rådighed for den totale reproduktionsproces, finder kun anvendelse som fungerende kapital, fordi en individuel kapital har brug for den for at udvide sine operationer. Denne udvidelse er et aspekt af den relative merværdiproduktion (i den industrielle kapitals tilfælde) eller af formindskelsen af de samlede samfundsmæssige cirkulationsomkostninger (i den cirkulerende kapitals tilfælde). Hvorledes denne udvidelse påtvinges individerne gennem kon- 
kurrencens mekanismer er et tema for konkurrenceanalysen (jvf. Eldred 1984, $\S \S 28,29,35,36)$

»... konkurrencen påtvinger den enkelte kapitalist uden undtagelse den kapitalistiske produktionsmådes immanente love som ydre tvangslove. Konkurrencen tvinger kapitalisten til hele tiden at udvide sin kapital for at bevare den, og han kan kun udvide den gennem progressiv akkumulation.« (Rh. 1.4, 837; K1 618)

»En videnskabelig analyse af konkurrencen er kun mulig, i det øjeblik man forstår kapitalens indre natur.« (Rh. 1.2, 475; K 1335$)$

\section{$\S 64$}

Den totale samfundsmæssige kapitals reproduktionsproces er reproduktion indenfor uforandrede formrelationer. Produktet produceres som vare indenfor en fungerende kapitals kredsløb, hvor arbejdere under lønrelationen og jord gennem leje indlemmes i arbejdsprocessen. Uanset de kvantitative proportioner af vareprodukt, priser, lånekapital osv., så reproducerer reproduktionsprocessen værdiformsrelationerne.

Klasserelationerne reproduceres og mere specifikt reproduceres arbejderklassen, der i næste periode atter tilbyder sin arbejdskraft til leje for den aktive kapitalist. Bortset fra individuelle undtagelser, så reproducerer arbejderklassens individuelle konsumtion den som arbejderklasse, som levende materiale for kapitalens valorisering gennem produktion og cirkulation. En historisk bevægelse hinsides denne reproduktionscirkel forudsætter den bevidste foregribelse af et alternativ.

a) Marx behandler reproduktionen af kapital-lønarbejderrelationen som et aspekt af kapitalens reproduktion allerede i syvende afsnit i 1. bind (Rh. 1.4, 801; K1 589). Det er slående, at reproduktionen ikke blot undersøges i slutningen af 2. bind, men også i slutningen af 1 . bind. De restriktive antagelser Marx gør vedrørende reproduktionsskemaerne, reducerer effektivt reproduktionsanalysen til produktionsanalysens systematiske niveau. Den eneste begrebslige udvikling i cirkulationsanalysen, som substantielt tages i betragtning, er begrebet om fix og cirkulerende kapital. Bortset fra dette enkelte emne, så adskiller behandlingen af reproduktionen i afsnit 3 i 2. bind sig ikke substantielt fra præsentationen af det samme spørgsmål i afsnit 7 i 1. bind. Marx' dobbelte behandling af dette emne kan kun fortolkes som endnu et tegn på den kendsgerning, at »Kapitalen ... på trods af Engels' tilføjelser er forblevet en torso«. (H. Cunow. Die Marxsche Geschichte-, Gesellschafts- und Staatstheorie, Bd. 1, Berlin 1920, p. 6).

b) Denne afslutning på den vardiformsanalytiske rekonstruktion af Kapitalen forbereder overgangen til en formanalytisk konkurrenceanalyse. Med 
den tiltagende mystifikation af kapitalprocessen gennem den stadig tiltagende udvendiggørelse af kapitalbegrebet og den voksende rolle som det særegne har spillet $\mathrm{i}$ analysen, er vi trinvis nået det kapitalistiske samfunds overflade, nemlig den фkonomiske konkurrence, båret af individerne, som er drevet frem af partikulariseringen af den totale kapitalbevægelse. Præsentationen kan således ikke hvile på det niveau, vi har nået her. Den læser, som også $\emptyset$ nsker at forstå helheden $i$ tanken kan ikke stille sig tilfreds med dette niveau i den dialektiske dialog.

Læs mere om denne kapitalanalyse og dens videreudvikling til statsanalyse $\mathrm{i}$

Michael Eldred:

Critique of Competitive Fredom and the Borgeois-Democratic State

\section{Outline of a form-analystic extension of Marx's uncompleted system}

\section{Sydney-Konstans Project 1984.}

Udgivet på engelsk af

\section{KURASJE}

520 sider. Pris: 270 kr. for abonnenter på Kurasje, $360 \mathrm{kr}$. for andre. 